\title{
Strictosidine Synthase: Mechanism of a Pictet-Spengler Catalyzing Enzyme
}

\author{
Justin J. Maresh ${ }^{\dagger}$, Lesley-Ann Giddings ${ }^{\dagger}$, Anne Friedrich ${ }^{\dagger}$, Elke A. Loris $\ddagger$, Santosh \\ Panjikar $\S$, Bernhardt L. Trout $\|$, Joachim Stöckigt ${ }^{\ddagger}$, Baron Peters ${ }^{\perp}$, and Sarah E. \\ O'Connor $^{\dagger}$ \\ Department of Chemistry, Massachusetts Institute of Technology, Cambridge, Massachusetts \\ 02139, College of Pharmaceutical Sciences, Zhejiang University, Zijingang Campus, 310058 \\ Hangzhou, China, Lehrstuhl für Pharmazeutische Biologie, Institut für Pharmazie, Staudingerweg \\ 5, 55099 Mainz, Germany, European Molecular Biology Laboratory, Hamburg outstation DESY, \\ Notkestrasse 85, 22603 Hamburg, Germany, Department of Chemical Engineering, \\ Massachusetts Institute of Technology, Cambridge, Massachusetts 02139, and Department of \\ Chemical Engineering, University of California, Santa Barbara, Santa Barbara, California 93106
}

\section{Abstract}

The Pictet-Spengler reaction, which yields either a $\beta$-carboline or a tetrahydroquinoline product from an aromatic amine and an aldehyde, is widely utilized in plant alkaloid biosynthesis. Here we deconvolute the role that the biosynthetic enzyme strictosidine synthase plays in catalyzing the stereoselective synthesis of a $\beta$-carboline product. Notably, the rate-controlling step of the enzyme mechanism, as identified by the appearance of a primary kinetic isotope effect (KIE), is the rearomatization of a positively charged intermediate. The KIE of a nonenzymatic Pictet-Spengler reaction indicates that rearomatization is also rate-controlling in solution, suggesting that the enzyme does not significantly change the mechanism of the reaction. Additionally, the $\mathrm{pH}$ dependence of the solution and enzymatic reactions provides evidence for a sequence of acid-base catalysis steps that catalyze the Pictet-Spengler reaction. An additional acid-catalyzed step, most likely protonation of a carbinolamine intermediate, is also significantly rate controlling. We propose that this step is efficiently catalyzed by the enzyme. Structural analysis of a bisubstrate inhibitor bound to the enzyme suggests that the active site is exquisitely tuned to correctly orient the iminium intermediate for productive cyclization to form the diastereoselective product. Furthermore, ab initio calculations suggest the structures of possible productive transition states involved in the mechanism. Importantly, these calculations suggest that a spiroindolenine intermediate, often invoked in the Pictet-Spengler mechanism, does not occur. A detailed mechanism for enzymatic catalysis of the $\beta$-carboline product is proposed from these data.

\footnotetext{
Correspondence to: Joachim Stöckigt; Baron Peters; Sarah E. O’Connor.

$\dagger$ Department of Chemistry, Massachusetts Institute of Technology.

\$Institut für Pharmazie and Zhejiang University.

$\S$ European Molecular Biology Laboratory.

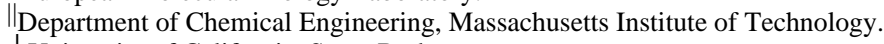

$\perp_{\text {University of California, Santa Barbara. }}$
}

Supporting Information Available: Figures S1-S14 and Tables S1-S3: characterization of the transient intermediate observed in the nonenzymatic reaction, representative solution kinetics data, the buffer and $\mathrm{pH}$ dependence of reaction with substrate $\mathbf{5}$, dependence

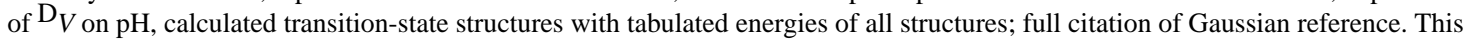
material is available free of charge via the Internet at http://pubs.acs.org.

JA077190Z 


\section{Introduction}

The Pictet-Spengler reaction yields $\beta$-carboline and tetrahydroquinoline structures essential to the biosynthesis of thousands of plant natural products. Enzymes that catalyze this reaction have been isolated from several plant alkaloid biosynthetic pathways. ${ }^{1-3}$ Strictosidine synthase, ${ }^{4,5}$ one "Pictet-Spenglerase," is the central enzyme in the biosynthesis of the monoterpene indole alkaloids. These alkaloids are a large and structurally diverse family of natural products that include vinblastine, yohimbine, ajmaline, camptothecin, and strychnine and are found in a wide variety of plant species. ${ }^{6,7}$ Strictosidine synthase diastereoselectively converts the substrates tryptamine $1 \mathbf{a}$ and secologanin 2 to the $\beta$ carboline product strictosidine $\mathbf{3}$ (Figure 1). Strictosidine $\mathbf{3}$ serves as the biosynthetic precursor to all terpene indole alkaloids.

The Pictet-Spengler reaction is essentially a two-part reaction. ${ }^{8,9}$ First, an electron-rich aromatic amine and an aldehyde condense to form an iminium species (Figure 1, steps 1-3). Second, an electrophilic aromatic substitution reaction occurs in which the aryl amine attacks the electrophilic iminium to yield a positively charged intermediate (Figure 1, step 4) which is then deprotonated to yield the $\beta$-carboline product(s). In nonenzymatically catalyzed reactions, two enantiomers are typically formed, but strictosidine synthase catalyzes the asymmetric synthesis of the strictosidine $\mathbf{3}$ diastereomer (asterisk in Figure 1).

Notably, both carbons 2 and 3 of tryptamine are nucleophilic (Figure 1). Therefore, after iminium formation, Pictet-Spengler reactions that utilize indole amine substrates can proceed either by attack of carbon 2 to directly yield the six-membered ring intermediate (Figure 1, step 4) or by attack of carbon 3 to yield a spiroindolenine intermediate (Figure 1, step 4a) that would then undergo a 1,2-alkyl shift (Figure 1, step 4b) to form the product. Evidence for both mechanisms in solution exists, and the predominant mechanism is not entirely clear. ${ }^{10-13}$ The mechanism for the enzymatic reaction is not known.

Strictosidine synthase (Rauvolfia serpentina) has been cocrystallized in the presence of both secologanin (PDB code 2FPC) and tryptamine (PDB code 2FPB), ${ }^{14}$ and these structures have allowed the first insights into the substrate binding orientation and enzymatic mechanism. Strictosidine synthase, originally isolated from Catharanthus roseus and $R$. serpentina almost 30 years ago, ${ }^{15,16}$ has been the subject of numerous steady-state kinetic analyses (for two examples, see refs ${ }^{17,18}$ ). $K_{\mathrm{m}}$ values have been reported for both tryptamine $1(4 \mu \mathrm{M})$ and secologanin $2(40 \mu \mathrm{M})$, and values previously reported from our laboratory match literature values. ${ }^{19,20}$ The recently reported strictosidine synthase crystal structure revealed the presence of only three ionizable residues in the active site, Tyr151, His307, and Glu309 ( $R$. serpentina numbering), that were located near the amine of tryptamine 1 and the aldehyde of secologanin 2 (Figure 2). ${ }^{14}$ His 307 appears to be involved in binding to the glucose moiety of secologanin as evidenced by the crystal structure and the large increase in secologanin $K_{\mathrm{m}}$ after mutation. ${ }^{14}$ Site-directed mutagenesis of Tyr151 suggests that the ionizable hydroxyl group does not play an important role in catalysis. ${ }^{14}$ Site-directed mutagenesis experiments do support the involvement of glutamate residue (Glu309, R. serpentina numbering) in catalysis (900-fold drop in $V_{\max }$ for Glu309Ala). ${ }^{14,19}$

This structural information provides an excellent foundation for further mechanistic study of the Pictet-Spengler reaction. Here we report specific roles for acid-base catalysis in strictosidine synthase using data derived from kinetic isotope effects (KIE), rate dependence on $\mathrm{pH}$, and comparisons to a nonenzymatic Pictet-Spengler reaction. The data suggest the involvement of both an acid-catalyzed step involved in iminium formation (Figure 1, step 3) and a base-catalyzed step involved in the final deprotonation step (Figure 1, step 5). We propose that an active-site glutamate residue previously implicated by site-directed 
mutagenesis, ${ }^{14}$ as well as the protonated tryptamine substrate, are the mediators of this acidbase chemistry. Strictosidine synthase does not appear to alter the mechanism of the reaction, since the KIE data show similar rate-controlling rearomatization in solution and in the enzymatic reaction. Additionally, $a b$ initio and crystallographic studies provide insight into the nature of the enzyme binding site and the productive transition states involved in the reaction. Notably, these $a b$ initio calculations suggest that formation of the spiroindolenine intermediate shown in Figure 1 (step 4a) is not an important part of the Pictet-Spengler mechanism and that 1,2-alkyl shift of this intermediate (Figure 1, step 4b) does not occur.

\section{Materials and Methods}

\subsection{General}

All reagents except for secologanin were purchased from Sigma-Aldrich and used without further purification unless otherwise noted. Secologanin was isolated as previously described. ${ }^{20}$ HPLC analysis was carried out on a Beckman Coulter System Gold 125 HPLC equipped with a model 168 photodiode array detector, Hibar RT 250-4LiCHrosorb C18 column (Merck), and a home-built column heater set to maintain $30^{\circ} \mathrm{C}$. Preparative HPLC was performed on a Beckman Coulter System Gold 127P HPLC equipped with a model 116P single wavelength detector and a Grace Vydac C18 column. Mass spectroscopy data were obtained on a Waters UPLC-TOF-MS. ${ }^{1} \mathrm{H}$ and ${ }^{13} \mathrm{C}$ 1D NMR spectroscopy were recorded on either a Varian INOVA 500-MHz or Bruker AVANCE 400-MHz or 600-MHz NMR spectrometer. Two-dimensional NMR spectroscopy was recorded on a Bruker AVANCE 600-MHz NMR spectrometer.

\subsection{Synthesis of $\left[2-{ }^{2} \mathrm{H}\right]-$ Tryptamine $1 \mathrm{~b}$}

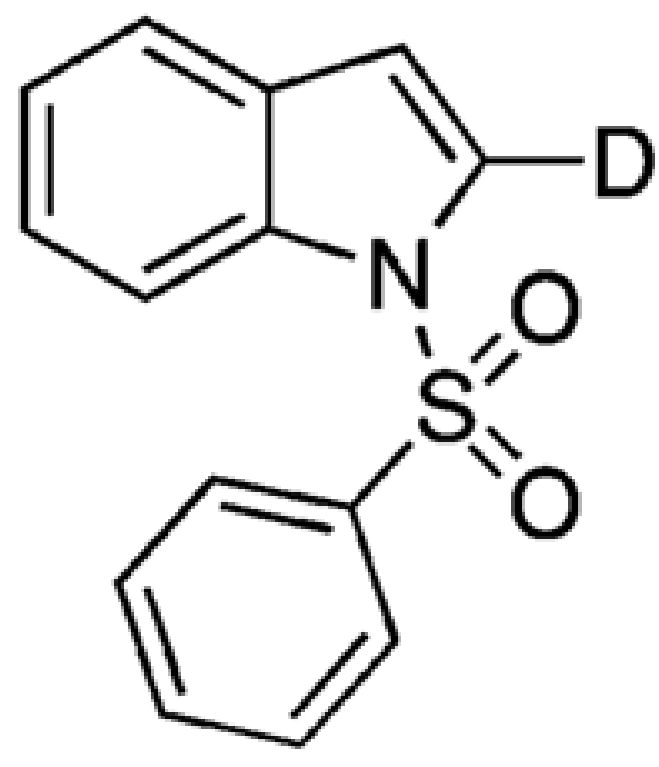

2.2.1. $\left[2-{ }^{2} \mathrm{H}\right]-1-($ Phenylsulfonyl)indole-To a stirring solution of 1(phenylsulfonyl)indole $(1.03 \mathrm{~g}, 4.00 \mathrm{mmol}$, Aldrich) in dry THF $(20 \mathrm{~mL})$ under dry nitrogen atmosphere, $n$-butyllithium $\left(1.8 \mathrm{M}, 8 \mathrm{mmol}\right.$, Aldrich) was added dropwise at $-78{ }^{\circ} \mathrm{C}$. The orange mixture was allowed to warm to $20^{\circ} \mathrm{C}$ over $2 \mathrm{~h}$ and stirred for $1 \mathrm{~h}$ during which time a precipitate formed. The solution was recooled to $-78{ }^{\circ} \mathrm{C}$, and $\mathrm{D}_{2} \mathrm{O}(1 \mathrm{~mL})$ was added dropwise. The reaction was allowed again to warm to $20^{\circ} \mathrm{C}$ and stirred for 30 min during 
which time a yellow precipitate formed. The reaction was quenched with solid $\mathrm{K}_{2} \mathrm{CO}_{3}$ and stirred with $50 \mathrm{~mL}$ of dry ether. After the solution clarified, the reaction mixture was filtered and concentrated in vacuo to yield $992 \mathrm{mg}(96 \%)$ of crude product as amber oil. Purification by silica gel chromatography (9:1 hexanes/ethyl acetate) yielded $951 \mathrm{mg}(92 \%)$ of white crystalline solid. Alternatively, recrystallization from ether yielded $876 \mathrm{mg}(85 \%)$ of white crystals: $\mathrm{mp} 81-82{ }^{\circ} \mathrm{C} ;{ }^{1} \mathrm{H}$ NMR $\left(\mathrm{CDCl}_{3}, 400 \mathrm{MHz}\right): \delta 6.67(1 \mathrm{H}, \mathrm{s}), 7.21-7.26(1 \mathrm{H}, \mathrm{m})$, 7.29-7.35 (1H, m), 7.41-7.29 (2H, m), 7.50-7.55 (2H, m), $7.89(1.33 \mathrm{H}, \mathrm{dd}, J=1.4 \mathrm{~Hz}, 7.3$ partial deuteration of phenyl), $8.01(1 \mathrm{H}, \mathrm{dd}, 0.72,8.28)$. Relative to the commercial starting material, the doublet at $6.67 \mathrm{ppm}(J=3.7 \mathrm{~Hz})$, assigned as $3-{ }^{1} \mathrm{H}$, collapsed to a sharp singlet, and the doublet at $7.58 \mathrm{ppm}(J=3.7 \mathrm{~Hz})$ was absent. Deuteration of the 2-position was measured as $>98 \%$ by ${ }^{1} \mathrm{H}$ NMR.<smiles>[2H]c1cc2ccccc2[nH]1</smiles>

2.2.2. $\left[{ }^{2}-{ }^{2} \mathrm{H}\right]-$ Indole-A solution of $\mathrm{NaOH}(2.0 \mathrm{M}, 40 \mathrm{~mL})$ was added to a stirring solution of 2-deutero-1-(phenylsulfonyl)indole $(3.20 \mathrm{~g}, 12.4 \mathrm{mmol})$ in $30 \mathrm{~mL}$ of methanol and heated to reflux at $85^{\circ} \mathrm{C}$ under nitrogen overnight until starting material was consumed as monitored by TLC. Methanol was removed in vacuo and product was extracted with ether (5 $\times 20 \mathrm{~mL})$, washed with brine $(3 \times 5 \mathrm{~mL})$, dried over magnesium sulfate, and concentrated in vacuo to give $1.45 \mathrm{~g}$ (98\% yield) of a white solid: $\mathrm{mp} 51-52{ }^{\circ} \mathrm{C} ;{ }^{1} \mathrm{H} \mathrm{NMR}\left(\mathrm{CDCl}_{3}, 400\right.$ MHz): $\delta 6.57(1 \mathrm{H}, \mathrm{s}), 7.14(1 \mathrm{H}, \mathrm{dd}, J=7.8,8.1 \mathrm{~Hz}), 7.22(1 \mathrm{H}, \mathrm{dd}, J=7.8 \mathrm{~Hz}, 8.1), 7.40$ $(1 \mathrm{H}, \mathrm{d}, J=8.1 \mathrm{~Hz}), 7.69(1 \mathrm{H}, \mathrm{d}, J=7.8 \mathrm{~Hz}), 8.51(1 \mathrm{H}, \mathrm{NH}, \mathrm{br})$; ESI-MS $\mathrm{m} / z$ (rel intens): $119\left(\mathrm{MH}^{+}, 100\right), 120(14)$. Mass calibration was verified by mixing with natural abundance indole.

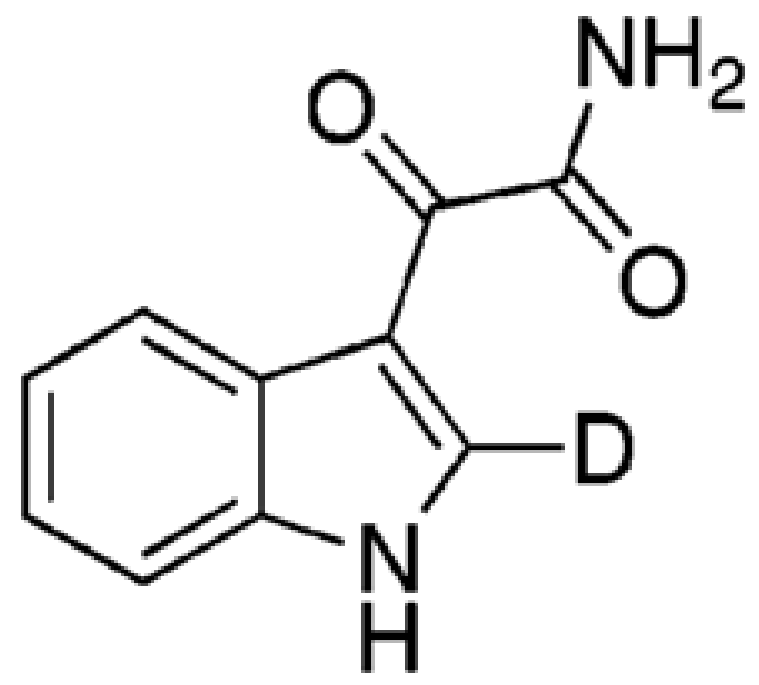

2.2.3. 2-([2-2 $\mathrm{H}]-1 \mathrm{H}-I n d o l-3-y l)-2-0 x o a c e t a m i d e-O x a l y l ~ c h l o r i d e ~(2.15 \mathrm{~mL}, 25.4$ $\mathrm{mmol}$ ) was added dropwise by syringe to a stirred solution of 2-deutero-indole (1.0 g, 8.46 $\mathrm{mmol}$ ) in dry ether under argon at $0{ }^{\circ} \mathrm{C}$. It was critical that the oxalyl chloride was free of $\mathrm{HCl}$, or else the deuterium label would be lost. The reaction was allowed to warm to ambient temperature and was stirred for $1 \mathrm{~h}$. The stirring was then stopped, the solids were allowed to settle, and excess solution was removed by syringe and discarded. Ammonia in 
dioxane $(25 \mathrm{~mL}, 2.0 \mathrm{M})$ was then added to a cooled solution of the crude product in dry ether under argon. After stirring overnight at ambient temperature, solid $\mathrm{NaHCO}_{3}$ was added, and the solvent was evaporated under vacuum. The resulting solid was loaded dry onto a silica column for purification by flash chromatography $\left(9: 1 \rightarrow 7: 3 \mathrm{CH}_{2} \mathrm{Cl}_{2} / \mathrm{CH}_{3} \mathrm{OH}\right)$ to yield $1.59 \mathrm{~g}(93 \%)$ of a white solid. ${ }^{1} \mathrm{H}$ NMR (acetone- $\left.d_{6}, 400 \mathrm{MHz}\right): \delta 7.93(1 \mathrm{H}, \mathrm{br}$, $\left.\mathrm{NH}_{2}\right), 7.26-7.29(2 \mathrm{H}, \mathrm{m}), 7.55-7.58(1 \mathrm{H}, \mathrm{m}), 7.65\left(1 \mathrm{H}, \mathrm{br}, \mathrm{NH}_{2}\right), 8.35-8.37(1 \mathrm{H}, \mathrm{m}), 11.25$ (1H, br, NH); ESI-MS m/z (rel intens): $190\left(\mathrm{MH}^{+}, 100\right), 191\left(\mathrm{MH}^{+}+1,9\right)$.

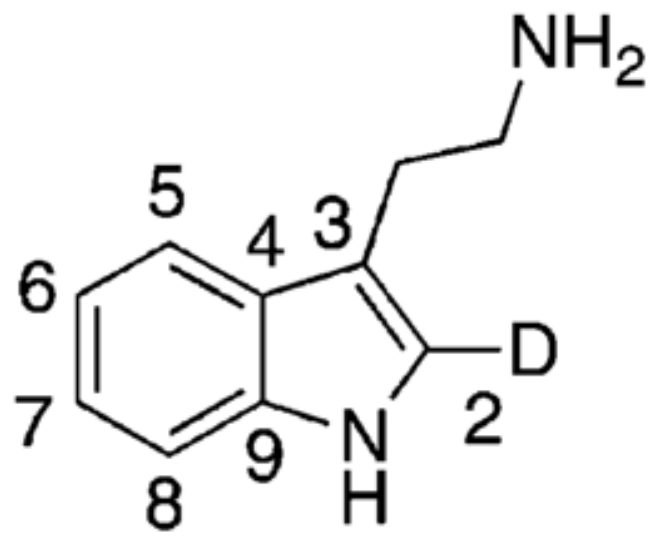

2.2.4. $\left[{ }^{2}{ }^{2} \mathrm{H}\right]-$ Tryptamine-Lithium aluminum hydride $(10 \mathrm{~mL}, 1.0 \mathrm{M})$ was added slowly to a stirring solution of 2-(2-deutero-1H-indol-3-yl)-2-oxoacetamide (189 mg, $1.00 \mathrm{mmol})$ in $50 \mathrm{~mL}$ of dry 1,4-dioxane under argon at room temperature over $30 \mathrm{~min}$. At this time, the reaction mixture was heated to $110^{\circ} \mathrm{C}$ and refluxed. After $50 \mathrm{~h}$, wet dioxane was added cautiously until lithium aluminate precipitated from the reaction mixture. This mixture was filtered warm through a medium-porosity fritted glass filter and washed with $100 \mathrm{~mL}$ of hot dioxane; the combined filtrates were dried over anhydrous sodium carbonate, and solvent was removed in vacuo to yield an amber oil (crude yield 77\%). This oil was purified by preparative RP-HPLC (C18, gradient of water with $0.1 \%$ TFA and acetonitrile), evaporated three times from $\mathrm{H}_{2} \mathrm{O}$ to afford $165 \mathrm{mg}(60 \%)$ product as a TFA salt. 1H NMR (400 MHz, $\left.\mathrm{D}_{2} \mathrm{O}\right): \delta 7.53(\mathrm{~d}, J=9.80 \mathrm{~Hz}, 1 \mathrm{H}), 7.39(\mathrm{~d}, J=8.17 \mathrm{~Hz}, 1 \mathrm{H}), 7.13(\mathrm{t}, J=7.58 \mathrm{~Hz}, 1 \mathrm{H}), 7.05$ (t, $J=7.23 \mathrm{~Hz}, 1 \mathrm{H}), 3.16(\mathrm{t}, J=6.98 \mathrm{~Hz}, 1 \mathrm{H}), 3.00(\mathrm{t}, J=6.99 \mathrm{~Hz}, 1 \mathrm{H})$. ESI-MS $m / z$ (rel intens): $162\left(\mathrm{MH}^{+}, 100\right), 163\left(\mathrm{MH}^{+}+1,3\right) .{ }^{13} \mathrm{C} \mathrm{NMR}\left(101 \mathrm{MHz}, \mathrm{D}_{2} \mathrm{O}\right): \delta 136.9$ (C9), 127.0 (C4), 122.8 (C7), 120.02 (C5), 118.9 (C6), 112.7 (C8/C3), 109.5 (C3/C8), $40.3\left(\mathrm{CH}_{2}\right), 23.2$ $\left(\mathrm{CH}_{2} \mathrm{~N}\right)$. Exact mass (ESI-MS): $\mathrm{m} / z$ 162.1141 $\left(\mathrm{MH}^{+}\right)$, expected 162.1136. The isotopic enrichment of $2{ }^{2} \mathrm{H}$ was measured by ESI-TOF mass spectrometry to be $90.417 \pm 0.01 \%$.<smiles>NCCc1c[nH]c2ccccc12</smiles>

\subsection{Synthesis of Natural Abundance Tryptamine 1a}

The identical procedure was followed for synthesis of natural abundance tryptamine except $\mathrm{H}_{2} \mathrm{O}$ was substituted for $\mathrm{D}_{2} \mathrm{O}$ following directed lithiation. Similar yields were obtained. 
Characterization of final product: ${ }^{1} \mathrm{H}$ NMR $\left(400 \mathrm{MHz}, \mathrm{D}_{2} \mathrm{O}\right): \delta 7.53(\mathrm{~d}, J=7.93 \mathrm{~Hz}, 1 \mathrm{H})$, $7.40(\mathrm{~d}, J=8.18 \mathrm{~Hz}, 1 \mathrm{H}), 7.16(\mathrm{~s}, 1 \mathrm{H}), 7.14(\mathrm{t}, J=7.26 \mathrm{~Hz}, 1 \mathrm{H}), 7.05(\mathrm{t}, J=7.50 \mathrm{~Hz}, 1 \mathrm{H})$, $3.16(\mathrm{t}, J=7.00 \mathrm{~Hz}, 1 \mathrm{H}), 3.01(\mathrm{t}, J=7.00 \mathrm{~Hz}, 1 \mathrm{H}) .{ }^{13} \mathrm{C} \mathrm{NMR}\left(126 \mathrm{MHz}, \mathrm{D}_{2} \mathrm{O}\right): \delta 136.9$ (C9), 127.0 (C4), 124.8 (C2), 122.7 (C7), 119.96 (C5), 118.8 (C6), 112.6 (C8/C3), 109.6 $(\mathrm{C} 3 / \mathrm{C} 8), 40.3\left(\mathrm{CH}_{2}\right), 23.2\left(\mathrm{CH}_{2} \mathrm{~N}\right)$. Exact mass (ESI-TOF): $\mathrm{m} / z 161.1076\left[\mathrm{MH}^{+}\right]$, expected 161.1073.<smiles>C=C[C@@H]1[C@H](OCl)OC=C(C(=O)OC)[C@@H]1CCNCCc1c[nH]c2ccccc12</smiles>

\subsection{Synthesis of Inhibitor 6}

A solution of sodium cyanoborohydride $(0.086 \mathrm{mmol}$, in $10 \mathrm{~mL}$ methanol $)$ was added to $31.0 \mathrm{mg}(0.158 \mathrm{mmol})$ of tryptamine hydrochloride and 5 activated molecular sieves in dry methanol $(1 \mathrm{~mL})$. Secologanin $(50.0 \mathrm{mg}, 0.129 \mathrm{mmol})$ dissolved in methanol $(1 \mathrm{~mL})$ was slowly added to reaction mixture over $4 \mathrm{~h}$. The reaction was quenched by addition of 400 $\mathrm{mg}$ of MP-TsOH resin (Biotage). After $1 \mathrm{~h}$ of shaking, the resin was washed with dichloromethane $(10 \mathrm{~mL})$ and eluted with ammonia $(1 \mathrm{M})$ in methanol. The ammonia fraction was collected and evaporated to dryness. The product was purified by preparative RP-HPLC using a $20 \mathrm{~mm} \times 30 \mathrm{~mm}$ reverse-phase C18 column. Using a 20-50\% gradient of acetonitrile: formic acid $(0.05 \%)$, afforded $4.2 \mathrm{mg}(5 \%$ yield $\mathrm{w} / \mathrm{w})$ of white solid product.

${ }^{1} \mathrm{H}$ NMR (500 MHz, CD $\left.{ }_{3} \mathrm{OD}\right): \delta 1.86-1.99(\mathrm{~m}, 1 \mathrm{H}), 2.63-2.64(\mathrm{~m}, 1 \mathrm{H}), 2.81-2.85$ (m, 1 H), 3.04-3.16 (m, 2 H), 3.16-3.38 (m, 12 H), 3.63-3.69 (m, $4 \mathrm{H}), 3.86$ (dd, $J=5.2,5.1 \mathrm{~Hz}$, $2 \mathrm{H}), 3.91(\mathrm{dd}, J=11.8,1.7 \mathrm{~Hz}, 1 \mathrm{H}), 4.69(\mathrm{~d}, J=7.9 \mathrm{~Hz} 1 \mathrm{H}), 5.28(\mathrm{~d}, J=10.6 \mathrm{~Hz}, 1 \mathrm{H})$, $5.31(\mathrm{~d}, J=17.3 \mathrm{~Hz}, 1 \mathrm{H}), 5.54(\mathrm{~d}, J=6.6 \mathrm{~Hz}, 1 \mathrm{H}), 5.70-5.79(\mathrm{~m}, 1 \mathrm{H}), 7.05(\mathrm{dd}, J=7.7$, $7.2 \mathrm{~Hz}, 1 \mathrm{H}), 7.12(\mathrm{dd}, J=7.6,7.4 \mathrm{~Hz}, 1 \mathrm{H}), 7.19(\mathrm{bs}, 1 \mathrm{H}), 7.38(\mathrm{~d}, J=8.1 \mathrm{~Hz}, 1 \mathrm{H}), 7.55$ (bs, $1 \mathrm{H}), 7.60(\mathrm{~d}, J=7.9 \mathrm{~Hz}, 1 \mathrm{H}), 8.50$ (bs, $1 \mathrm{H}) .{ }^{13} \mathrm{C} \mathrm{NMR}\left(125 \mathrm{MHz}, \mathrm{CD}_{3} \mathrm{OD}\right): \delta 23.5$, 27.9, 31.9, 45.2, 47.5, 52.1, 57.1, 57.4, 62.9, 71.7, 74.7, 78.0, 78.6, 97.5, 100.2, 109.9, 110.0, 112.6, 119.0, 120.1, 122.8, 124.3, 128.2, 135.01, 138.4, 154.8, 169.5. Exact mass (ESI-TOF): [M+ ${ }^{+}$, calc: 533.2499, found: 533.2495.

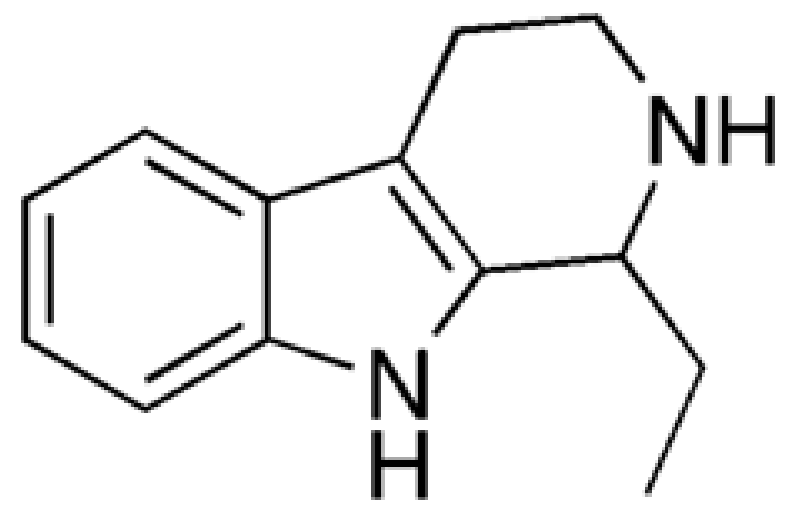




\subsection{Synthesis of 1-Ethyl-2,3,4,9-tetrahydro-1H-pyrido[3,4-b]-indole 7}

This compound was used as an authentic standard in model chemical reactions. Propionaldehyde $(1.91 \mathrm{~g}, 33.0 \mathrm{mmol})$ dissolved in $10 \mathrm{~mL}$ of water was added to a stirring suspension of tryptamine $\mathrm{HCl}(590 \mathrm{mg}, 3.0 \mathrm{mmol})$ in $5 \mathrm{~mL}$ of methanol, $15 \mathrm{~mL}$ of water, and $215 \mu \mathrm{L} \mathrm{H}_{2} \mathrm{SO}_{4}(4.0 \mathrm{mmol})$. The solution was heated and stirred with reflux condenser at $50{ }^{\circ} \mathrm{C}$ for $16 \mathrm{~h}$, was made basic by careful addition of concentrated $\mathrm{NH}_{4} \mathrm{OH}$, and was extracted with chloroform. The organic layer was washed with $1 \mathrm{~N} \mathrm{NH}_{4} \mathrm{OH}$ followed by saturated $\mathrm{NaCl}$, dried over $\mathrm{MgSO}_{4}$, and evaporated in vacuo to yield $600 \mathrm{mg}$ of golden brown oil. Silica gel chromatography using a gradient of pure $\mathrm{CH}_{2} \mathrm{Cl}_{2}$ to $9: 1 \mathrm{CH}_{2} \mathrm{Cl}_{2} / \mathrm{MeOH}$ afforded $494 \mathrm{mg}$ (82\% yield) of yellow crystalline solid. ESI-MS: $\mathrm{m} / \mathrm{z} 201.14$ (expected 201.14). ${ }^{1} \mathrm{H}$ NMR (400 MHz, $\mathrm{CD}_{3} \mathrm{OD}$ with DCl): $\delta 7.51$ (d, $\left.J=7.83 \mathrm{~Hz}, 1 \mathrm{H}, \mathrm{ArH}\right), 7.42$ (d, $J=8.11 \mathrm{~Hz}, 1 \mathrm{H}, \mathrm{ArH}), 7.18(\mathrm{t}, 1 \mathrm{H}, \mathrm{ArH}), 7.10(\mathrm{t}, 1 \mathrm{H}, \mathrm{ArH}), 4.46-4.39\left(\mathrm{~m}, 1 \mathrm{H}, \mathrm{CH}^{13}\right)$, 3.63-3.52 (m, 1H, $\left.\mathrm{CH}_{2} 11\right), 3.29-3.18$ (m, $\left.1 \mathrm{H}, \mathrm{CH}_{2} 11\right), 3.03-2.85$ (m, $\left.2 \mathrm{H}, \mathrm{CH}_{2} 10\right), 2.16$ $\left(\mathrm{dqd}, J=15.05,7.50,4.37 \mathrm{~Hz}, 1 \mathrm{H}, \mathrm{CH}_{2} 14\right), 1.97-1.79\left(\mathrm{~m}, 1 \mathrm{H}, \mathrm{CH}_{2} 14\right), 1.06(\mathrm{~m}, J=7.50$ $\left.\mathrm{Hz}, 3 \mathrm{H}, \mathrm{CH}_{3} 15\right)$. 13C NMR (101 MHz, $\mathrm{CD}_{3} \mathrm{OD}$ with $\left.\mathrm{DCl}\right): \delta 136.57,131.23,126.48$, $122.25,119.57,118.33,111.59,106.85,54.34,41.80,25.61,19.10,9.12$.

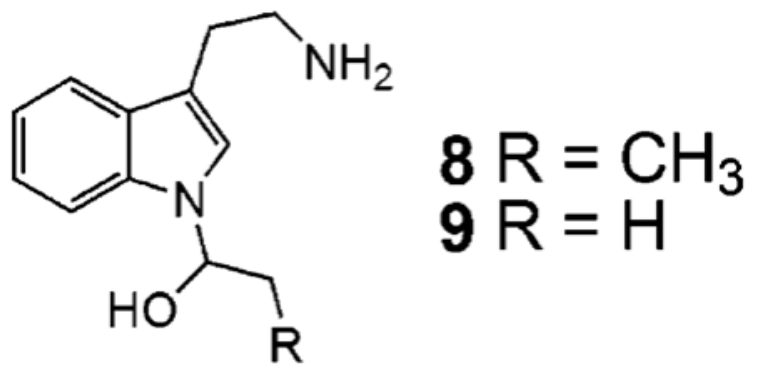

\subsection{Isolation of Intermediates 8 and 9}

The intermediates were prepared from reactions of $500 \mathrm{mM}$ propanal or acetaldehyde and 1 $\mathrm{mM}$ tryptamine in aqueous media acidified to $\mathrm{pH} 2$ with $\mathrm{HCl}$ to generate $\mathbf{8}$ and $\mathbf{9}$, respectively. The species $\mathbf{8}$ was isolated by preparative reverse-phase HPLC using a gradient of $20-50 \%$ aqueous trifluoroacetic acid $(0.1 \%)$ in acetonitrile. Fractions were chilled on ice and buffered with potassium phosphate $(50 \mathrm{mM}, \mathrm{pH} 5.0)$ to sufficiently stabilize the intermediate for evaporation to dryness (by SpeedVac) and characterization by NMR (see Supporting Information).

\subsection{Enzymatic Assays}

Strictosidine synthase (C. roseus) was expressed, and activity was measured using an HPLC assay following previously reported procedures. ${ }^{20}$ Strictosidine synthase $(80 \mathrm{nM})$ was incubated with secologanin and an internal standard in buffer at $30^{\circ} \mathrm{C}$. 1-Naphthalene-acetic acid (NAA) was used as an internal standard at a final concentration of $30 \mu \mathrm{M}$. This standard had no effect on the rate of reaction. Reactions were started by addition of tryptamine (1a or 1b).

$\mathrm{D}_{(V / K)}$ values were measured with one substrate varied and the other held at a concentration of at least 50 times $K_{\mathrm{m}}$. For $(V / K)_{\text {tryp }}$, secologanin was held at $2.5 \mathrm{mM}$ and tryptamine varied over $0.07-400 \mu \mathrm{M}$. For $(V / K)_{\text {sec }}$, tryptamine was held at $1.0 \mathrm{mM}$, and secologanin concentrations were varied ( $3.13 \mu \mathrm{M}$ to $1.6 \mathrm{mM})$. The greater error in reported $V / K$ over $V$ values is due to reduced sensitivity of the HPLC assay to changes in the low micromolar range. The actual concentrations of tryptamine and secologanin were measured from control samples and calculated from their area-extinction coefficients. The area-extinction 
coefficient for tryptamine was measured directly from standards and for secologanin from reaction with 2,4-dinitrophenyl hydrazide in $\mathrm{pH} 5$ acetic acid buffer.

Enzymatic reactions were quenched by addition $2.0 \mathrm{M}$ aqueous sodium hydroxide at 2 molar equiv over the buffer concentration to denature the enzyme and prevent any background Pictet-Spengler condensation. Under these quench conditions the methyl ester of both secologanin $\mathbf{2}$ and strictosidine $\mathbf{3}$ were quantitatively hydrolyzed, and no side products resulting from this hydrolysis were observed. Initial rates were obtained from five time points. Quenched aliquots $(74 \mu \mathrm{L})$ of the reaction were directly injected onto an analytical HPLC using a solvent gradient of $22 \%$ to $67 \%$ acetonitrile in $0.1 \%$ aqueous trifluoroacetic acid. The absorbance of tryptamine, strictosidine, and NAA was measured at 228 and 280 $\mathrm{nm}$ and exported to Excel spreadsheet software (Microsoft Corp.) for further analysis.

Strictosidine peak areas were integrated and normalized to the internal standard. Initial rates were determined from the slope by linear least-squares fit of five normalized data points for each concentration of varied substrate. Kinetic parameters $V, V / K$, and $K_{\mathrm{m}}$ were estimated from the initial rates directly fit to appropriate forms of the Michaelis-Menten equation ${ }^{21}$ by nonlinear least-squares fit using Origin 7.0 software (OriginLab Corp.).

To avoid interference from potential trace impurities in $\mathbf{1 b}$, the natural abundance substrate $\mathbf{1 a}$ was synthesized and purified under conditions identical to those for $\mathbf{1 b}$ to ensure that any trace impurities would be present in both labeled and unlabeled samples. Isotope effects on $V$ and $V / K$ were determined by dividing the $V$ or $V / K$ values obtained with $\mathbf{1 a}$ from $\mathbf{1 b}$.

Although the isotopic substitution of $\mathbf{1 b}$ was $90.42 \%$, reported, KIE values were not corrected. Unlike the case of competitive KIE measurements, the applied isotopic corrections for the direct measurements in this work were not found to be significant (usually within the confidence interval of the uncorrected value).

\subsection{Buffers for Enzyme Kinetics}

For assays at $\mathrm{pH} 7.0,100 \mathrm{mM} \mathrm{NaH}_{2} \mathrm{PO}_{4}$, buffer was used. For $\log V$-pH profiles, two different buffer systems were prepared to control for specific buffer effects on enzyme activity. To control ionic strength, the "practical $\mathrm{p} K_{\mathrm{a}}{ }^{\prime}\left(\mathrm{p} K_{\mathrm{a}}{ }^{\prime}\right)$ at experimental conditions was calculated for each buffering agent from the Debye-Hückel equation as described by Ellis ${ }^{22}$ using $A=0.5161$ for $30{ }^{\circ} \mathrm{C} .{ }^{23} \mathrm{~A}$ set of constant composition buffers with a constant ionic strength $(I=0.20)$ were prepared from a mixed buffer system of acetic acid $\left(\mathrm{p} K_{\mathrm{a}}{ }^{\prime}=4.64\right)$, Tris $\left(\mathrm{p} K_{\mathrm{a}}{ }^{\prime}=6.32\right)$, and Bis-Tris $\left(\mathrm{p} K_{\mathrm{a}}{ }^{\prime}=8.00\right)$ following the procedure of Ellis 22 covering the $\mathrm{pH}$ of 3.7 to 8.76 (pH at $30^{\circ} \mathrm{C}: 3.70,4.20,4.62,5.06,5.52,5.89,6.89,6.37,6.83,7.29$, $7.81,8.27,8.76)$. Alternatively, overlapping constant ionic strength buffers $(I=0.31)$ were also used: citric acid ( $\mathrm{p} K_{\mathrm{a} 1}{ }_{1}=2.97, \mathrm{p} K_{\mathrm{a} 2}{ }_{2}=4.61, \mathrm{p} K_{\mathrm{a} 3}{ }_{3}=6.25$ ) covered the $\mathrm{pH}$ range from 3.1 to 9.46 (pH at $30^{\circ} \mathrm{C}: 3.10,3.42,3.79,4.10,4.40,4.79,5.12,5.59,6.14,6.67$, and 6.93), potassium phosphate buffers $\left(\mathrm{p} K_{\mathrm{a}_{2}}{ }^{\prime}=6.72\right)$ covered an overlapping $\mathrm{pH}$ range of 6.50 to 8.04 (pH at $30^{\circ} \mathrm{C}: 6.50,6.80,7.19,7.50,7.87$, and 8.04 ), and borate $\left(\mathrm{p} K_{\mathrm{a}}{ }^{\prime}=9.04\right)$ buffers were used for assays over a $\mathrm{pH}$ range of 8.17 to $9.19\left(\mathrm{pH}\right.$ at $30^{\circ} \mathrm{C}: 8.17,8.35,8.70,8.92$, and 9.19). Both buffer conditions yielded equivalent results; identical $\mathrm{p} K_{\mathrm{a}}$ values were calculated from both buffer systems.

\section{9. pH Rate Profiles}

The enzyme was incubated with secologanin $(2.5 \mathrm{mM})$, strictosidine synthase $(5 \mathrm{nM})$, and NAA internal standard and buffer (from pH 3.1 to 9.7 ) at $30^{\circ} \mathrm{C}$. Either $\mathbf{1 a}$ or $\mathbf{1 b}$ was added $(0.3 \mathrm{mM})$ to start the reaction. Samples were quenched with $2.0 \mathrm{M} \mathrm{NaOH}$ sufficient to adjust $\mathrm{pH}$ to $\sim 12$ by $\mathrm{pH}$ paper as interfering peaks were observed when the basic buffers were quenched with too much base. Initial rates from the slope of the linear fit of five data points 
were determined as described for enzyme assays above. The data was fit to a diprotic model shown in eq $1^{24,25}$ using Origin 7.0 (OriginLab Corp.).

$$
V=\frac{V_{\max }}{1+\frac{H}{K_{1}}+\frac{K_{2}}{H}}
$$

\subsection{Circular Dichroism}

CD measurements were obtained on an Aviv Instruments, Inc. circular dichroism spectrometer model 202 from 195 to $250 \mathrm{~nm}$. Each wavelength step was $1 \mathrm{~nm}$, and the averaging time for each wavelength was $6 \mathrm{~s}$. Three CD spectra were obtained and averaged for each sample at $30^{\circ} \mathrm{C}$. Scans of pure solvent were used for a baseline and subtracted from the protein measurements. All samples were degassed. Spectra were obtained of strictosidine synthase $(14 \mu \mathrm{M})$ in a $50 \mathrm{mM}$ phosphate buffer with $10 \%$ glycerol at $30{ }^{\circ} \mathrm{C}$. The $\mathrm{pH}$ was adjusted by adding concentrated $\mathrm{HCl}$ or $\mathrm{NaOH}$. The concentration of strictosidine synthase was estimated from the known extinction coefficient and absorbance at $280 \mathrm{~nm}$.

\subsection{Kinetic Assays of Solution Reaction}

Assays contained distilled propanal $(100 \mathrm{mM})$, tryptamine 1a or $\mathbf{1 b}(0.3 \mathrm{mM})$, internal standard NAA $(0.2 \mathrm{mM})$ and buffer at $30{ }^{\circ} \mathrm{C}$ (see Figure S9A, Supporting Information). Buffer concentration and $\mathrm{pH}$ were varied in acetic acid buffer $\left(\mathrm{p} K_{\mathrm{a}}{ }^{\prime}=4.60\right)$. Ionic strength was maintained at a constant ionic strength $(I=0.5)$ following the procedure described for enzymatic assay buffers. The assay was initiated by addition of tryptamine $1 \mathbf{a}$ or $\left[2-{ }^{2} \mathrm{H}\right]-$ tryptamine $\mathbf{1 b}$. The initial tryptamine concentration was determined from aldehyde-free control samples. Kinetic data were obtained by HPLC from the peak area at $280 \mathrm{~nm}$ and exported to Excel (Microsoft Corp.) for analysis. The measured area-extinction coefficient of each species was used to convert corrected areas to concentrations. The area-extinction coefficients of tryptamine, aldehyde, and product were measured from authentic samples. To measure the area-extinction coefficient of the intermediate, this species was isolated by preparative HPLC to approximately $100 \mu \mathrm{M}$. At $10^{\circ} \mathrm{C}$, the intermediate decomposed cleanly to tryptamine, and the area-extinction coefficient was determined from tryptamine appearance. The results of four replicate decomposition reactions were analyzed simultaneously by nonlinear least-squares fitting in Origin 7.0 (OriginLab Corp.).

These data were fit to various models using the Gepasi computer program ${ }^{26}$ to obtain the first-order rate constants. The best fit was obtained by a system of two coupled reversible rate equations taking into account the presence of the nonproductive intermediate as in Scheme 1 (see Supporting Information Figure S9B for example of quality of fit). For each experiment, the time course data for tryptamine, intermediate, and product at all aldehyde concentrations were simultaneously optimized to the kinetic model by fitting the four parameters in Scheme 1 (each bound from $10^{-14}$ to $10^{2}$ ) and the initial tryptamine concentration of each sample (bound from 0.1 to $0.4 \mathrm{mM}$ ). The fastest, most reliable method was found to be the Hooke and Jeeves pattern-based direct-search algorithm (50 maximum iterations, $10^{-8}$ convergence tolerance, and $\left.\rho=0.2\right)$. Order tests with varied tryptamine (10$1000 \mu \mathrm{M})$ and propanal (5-95 $\mathrm{mM})$ determined that the forward Pictet-Spengler reaction $\left(k_{\mathrm{P}}\right)$ was first order in tryptamine and aldehyde, and the forward side reaction $\left(k_{\mathrm{I}}\right)$ was first order in tryptamine and second order in aldehyde. The reverse reactions were both first order. 
To measure the parameters $k_{\mathrm{HA}}$ and $k_{\mathrm{A}}$ in eq 7 (Results and Discussion), the parameter $B_{\mathrm{t}}$ (total buffer) was defined as $B_{\mathrm{t}}=[\mathrm{AcOH}]+\left[\mathrm{AcO}^{-}\right]$. Substituting this into eq 7 to replace $\left[\mathrm{AcO}^{-}\right]$yields eq 2.

$$
k_{\mathrm{obs}}=k_{\mathrm{HA}}[\mathrm{AcOH}]+k_{\mathrm{A}}\left(B_{\mathrm{t}}-[\mathrm{AcOH}]\right)+k_{\mathrm{o}}
$$

Rearrangement of eq 2 yields eq 3 , the form used to plot Figure 5B and directly solve $k_{\mathrm{HA}}$ and $k_{\mathrm{a}}$ from the linear intercepts. Note that $\left.[\mathrm{AcOH}]\right) / B_{\mathrm{t}}$ in eq 3 is mathematically identical to fraction of $\mathrm{AcOH}\left(\mathrm{F}_{\mathrm{HA}}\right)$ plotted in Figure 5B

$$
\left(k_{\mathrm{obs}}-k_{\mathrm{o}}\right) / B_{\mathrm{t}}=k_{\mathrm{A}}+\left(k_{\mathrm{HA}}-k_{\mathrm{A}}\right)[\mathrm{AcOB}] / B_{\mathrm{t}}
$$

To solve for $k_{\mathrm{o}}$, the rate constants $k_{\mathrm{obs}}$ at a given $\mathrm{pH}$ were plotted against total buffer $B_{\mathrm{t}}$. This plot was then linearly extrapolated to zero buffer $\left(k_{\mathrm{o}}\right)$ by least-squares fitting. Each sample was corrected by $k_{\mathrm{o}}$ and $B_{\mathrm{t}}$ to find $\left(k_{\mathrm{obs}}-k_{\mathrm{o}}\right) / B_{\mathrm{t}}$. Samples of the same $\mathrm{pH}$ were then used to plot Figure 5B. The derived values for 1a are $k_{\mathrm{HA}}=6.2 \pm 0.3 \times 10^{-4}, k_{\mathrm{A}}=1.5 \pm 1.8$ $\times 10^{-5}, k_{\mathrm{O}}=(0.38 \pm 0.01)\left[\mathrm{H}^{+}\right]+\left(1.31 \pm 0.05 \times 10^{-5} \mathrm{M}^{-1} \mathrm{~s}^{-1}\right)$ and $\mathbf{1 b}$ are $k_{\mathrm{HA}}=2.3 \pm 0.3 \times$ $10^{-4}, k_{\mathrm{A}}=2.0 \pm 1.4 \times 10^{-5}, k_{\mathrm{O}}=(0.26 \pm 0.02)\left[\mathrm{H}^{+}\right]+\left(6.7 \pm 0.6 \times 10^{-6} \mathrm{M}^{-1} \mathrm{~s}^{-1}\right)$.

\subsection{Ab Initio Calculations}

Geometry optimizations and vibrational frequencies were computed using the $6-31 \mathrm{G}^{*}$ basis set and the PW1PW91 density functional (M. J. Frisch, Gaussian Inc., Wallingford, CT (2003). See Supporting Information for full citation.) which has recently been found to provide a better description of organic cyclization reactions than B3LYP. ${ }^{27}$ Transition states were found using the growing string method and a memory augmented eigenvector following algorithm. ${ }^{28}$ Single-point solvent-corrected energies were computed using Tomasi's polarized continuum model (PCM) with the 6-311+G* basis set and the PW1PW91 functional. All calculations and reported values were determined by the Gaussian '03 program. ${ }^{29}$

\subsection{Inhibition Kinetics of Inhibitor 6}

To assess whether compound $\mathbf{6}$ acted as an inhibitor for strictosidine synthase, $\mathrm{IC}_{50}$ was determined by HPLC with tryptamine $(20 \mu \mathrm{M})$, secologanin $(80 \mu \mathrm{M})$, internal standard NAA $(60 \mu \mathrm{M})$, phosphate buffer $(100 \mathrm{mM}, \mathrm{pH} 7.0)$, C. roseus strictosidine synthase $(10 \mathrm{nM})$, and inhibitor at $30^{\circ} \mathrm{C}$. The reaction was quenched with $2.0 \mathrm{M}$ sodium hydroxide (to $200 \mathrm{mM}$ final) at four time points. Tryptamine disappearance and strictosidine appearance were monitored at $280 \mathrm{~nm}$ for assays with inhibitor, respectively. Peak areas were normalized to the internal standard as in other experiments and initial rates determined as described for enzyme assays above. The rates were fit to a sigmoidal logistic curve with Origin 7.0 (OriginLab Corp.) with a Hill slope factor of 1 . An $\mathrm{IC}_{50}$-value of $3 \pm 0.5 \mathrm{nM}$ was obtained.

\subsection{Cocrystallization of Strictosidine Synthase with Inhibitor 6}

The strictosidine synthase gene (excluding the signal peptide) from $R$. serpentina was expressed in Escherichia coli and purified as previously described. ${ }^{30}$ The enzyme was concentrated to $4-5 \mathrm{mg} / \mathrm{mL}$ in $10 \mathrm{mM}$ Tris- $\mathrm{HCl}$, $\mathrm{pH} 8.0$, before crystallization. Crystals of strictosidine synthase in complex with inhibitor were obtained by cocrystallization in the presence of $0.1 \mathrm{mM}$ inhibitor in the enzyme solution using the hanging drop vapor diffusion 
method. The reservoir solution contained $0.8 \mathrm{M}$ potassium sodium tartrate tetrahydrate and 0.1 M HEPES, pH 7.3.

The crystals of strictosidine synthase-inhibitor complex were incubated for $20 \mathrm{~s}$ in the reservoir solution containing $23 \%$ glycerol prior to flash cooling at $100 \mathrm{~K}$ in a liquid nitrogen stream. X-ray data were collected using synchrotron radiation at the X11 beamline of EMBL-Hamburg. The complete data were collected to $3.0 \AA$ A resolution. ThedatawereprocessedusingDENZOandscaledusingSCALEPACK. $32^{31}$ The data collection statistics are shown in the Table 1. The scaled data was nonisomorphous with respect to the native data. The structure was solved using molecular replacement method using the AutoRickshaw software pipeline. ${ }^{32}$ The high-resolution structure of strictosidine synthase (PDB code 1FP8) was used as a search model. Within the pipeline, the program MOLREP ${ }^{33}$ was used for molecular replacement, and the rigid body positional as well as B-factor refinement was performed using the program CNS. ${ }^{34}$ The residual electron density for inhibitor was clearly visible and was built using the graphics program COOT ${ }^{35}$ Subsequent refinement procedures were carried out using the program REFMAC5. ${ }^{36}$ The final $R$ factor is $18.7 \%$ for all data in the resolution range $20-3.0 \AA\left(R_{\text {free }}=24.7 \%\right)$. Of the non-glycine residues, $85.6 \%$ fall in the most favored regions of a Ramachandran plot ${ }^{37}$ generated by PROCHECK. ${ }^{38}$ The refinement statistics are summarized in Table 1.

\section{Results and Discussion}

\subsection{Enzymatic Kinetic Isotope Effect: Rate-Controlling Step}

To probe the specific role that strictosidine synthase plays in catalysis, the KIE of the enzymatic reaction (C. roseus, $89 \%$ homology to the enzyme from $R$. serpentina) was measured with $\left[2-{ }^{2} \mathrm{H}\right]$-tryptamine $\mathbf{1 b}$ to determine which of the reaction steps could be rate controlling. Tryptamine 1a and $\left[2-{ }^{2} \mathrm{H}\right]$-tryptamine $\mathbf{1 b}$ (Figure 1) were prepared following parallel synthetic procedures, and the rates of reaction with these substrates were compared using an HPLC assay (Figure 3) ${ }^{39}$ At saturating concentrations of both substrates $\mathbf{1 a / b}$ and 2 and optimal pH 7.0, a primary isotope effect of $2.67 \pm 0.13$ for ${ }^{\mathrm{D}} V$ was observed at $30^{\circ} \mathrm{C}$, indicating that the loss of the proton at the indole 2-position under $V_{\max }$ conditions is rate controlling (Figure 1, step 5). ${ }^{40,41}$ The primary KIE of ${ }^{\mathrm{D}} V$ reveals that under $V_{\max }$ conditions, the chemical steps of the enzymatic reaction are largely rate limiting.

The ring closure and deprotonation of the Pictet-Spengler reaction (Figure 1, steps 4 and 5) is essentially an electrophilic aromatic substitution reaction. Since the aromaticity is broken during the cyclization step (Figure 1, step 4), it might be reasonable to assume that cyclization would be rate controlling ${ }^{42}$ and that no primary isotope effect would be observed with $\left[2-{ }^{2} \mathrm{H}\right]$-tryptamine $\mathbf{1 b}$. While it is true that some nonenzymatic electrophilic aromatic substitution reactions do exhibit small KIE values, there are in fact many examples that exhibit primary KIE values for the replaced proton at the site of electrophilic aromatic substitution. ${ }^{43,44}$ These previously reported primary KIE values indicate that the final deprotonation step (Figure 1, step 5) is very often rate limiting in nonenzymatic electrophilic aromatic substitution reactions.

The emergence of a primary KIE for nonenzymatic electrophilic aromatic substitution reactions appears to be sensitive to the rate of the reverse reaction. In other words, as the rate of the reverse reaction $k_{-3}$ increases relative to deprotonation $k_{4}$ (Figure 1), the deprotonation becomes rate controlling, and the observed KIE increases. ${ }^{45-48}$ Factors contributing to the emergence of primary KIEs include sterics, base and reactant concentrations, and the acidity of the leaving proton. ${ }^{44}$ Assuming that the steps prior to the rate-limiting deprotonation step are reversible in the enzyme active site, a primary KIE 
should be expected if the rates of the reverse reaction (i.e., $k_{-3}$ in Figure 1) are fast relative to the rate of deprotonation $\left(k_{4}\right.$ in Figure 1$)$.

\subsection{Enzymatic KIE under VIK Conditions}

A significant, but smaller, primary KIE was observed at limiting concentrations of either tryptamine $\mathbf{1 a} / \mathbf{b}$ or secologanin $2\left({ }^{\mathrm{D}}\left(V / K_{\text {tryp }}\right)=1.87 \pm 0.37\right.$ and $\left.{ }^{\mathrm{D}}\left(V / K_{\text {sec }}\right)=1.45 \pm 0.28\right)$ at $\mathrm{pH}=7.0$ and $30^{\circ} \mathrm{C}$. At conditions of low substrate, where $V / K$ is the pseudo-second-order rate constant, the active site is not saturated. For a substrate that reacts to give products faster than it dissociates from the enzyme-tryptamine-secologanin ternary complex (a "sticky" substrate"), the isotope effect on V/K is reduced by an external forward commitment to catalysis. ${ }^{49,50}$ Since ${ }^{\mathrm{D}}\left(V / K_{\text {tryp }}\right)$ is slightly greater than ${ }^{\mathrm{D}}\left(V / K_{\text {sec }}\right)$, the tryptamine substrate is likely released at a rate faster than the rate for release of secologanin from the enzyme-tryptamine-secologanin ternary complex.

Equation $4{ }^{50}$ describes the relationship between the Michaelis constant $\left(K_{\mathrm{m}}\right)$ and the dissociation constant $K_{\mathrm{D}}$. From the DV/K data, we estimate $K_{\mathrm{D}}$ for secologanin and tryptamine as $K_{\mathrm{D} \cdot ; \text { tryp }}=2 \mu \mathrm{M}\left(K_{\mathrm{m} \cdot \text {;ryp }}=4 \pm 1 \mu \mathrm{M}\right)$ and $K_{\mathrm{D} \cdot \mathrm{s}}=11 \mu \mathrm{M}\left(K_{\mathrm{m} \cdot \mathrm{s}}=39 \pm 4 \mu \mathrm{M}\right)$, respectively.

$$
\frac{\mathrm{D}_{V}-1}{\mathrm{D}_{(}(V / K)-1}=K_{\mathrm{m}} / K_{\mathrm{D}}
$$

The magnitude of $\mathrm{D}_{(V / K)}$ isotope effects also provides information about binding order for multisubstrate enzymes. For an ordered mechanism, ${ }^{\mathrm{D}}(V / K)$ approaches unity if the varied substrate binds first. ${ }^{51}$ At saturating concentrations of either tryptamine $\mathbf{1}$ or secologanin $\mathbf{2}$, primary KIE values greater than 1 were measured $\left(\mathrm{D}_{(}\left(V / K_{\text {tryp }}\right)=1.87 \pm 0.37\right.$ and ${ }^{\mathrm{D}}\left(V / K_{\text {sec }}\right)=$ $1.45 \pm 0.28$ ), suggesting that the substrates bind in random order. This is consistent with crystallographic evidence which demonstrates that both tryptamine 1a and secologanin 2 substrates can bind to strictosidine synthase independently of one another. ${ }^{14}$

3.2.1. Acid-Base Catalysis in Strictosidine Synthase-The $\mathrm{pH}$ dependence of kinetic parameters ( $V$ and $V / K$ ) can result from the titration of groups involved in catalysis/ substrate binding or maintenance of enzyme structural conformation. Enzyme conformational changes can also impact the kinetic parameters. However, the structure of strictosidine synthase without substrate compared to the enzyme structure bound to either tryptamine, secologanin, or a bisubstrate inhibitor (see below) are very similar. ${ }^{14}$ This suggests, although does not prove, that no major conformational enzyme rearrangements occur upon substrate binding. We therefore make the assumption that since the enzymesubstrate(s) complex dominates under $V_{\max }$ conditions, the $\mathrm{pH}$ dependence of this parameter of this enzymatic reaction is only sensitive to catalysis, not binding or conformation, when the chemical reaction is rate limiting. ${ }^{24,25}$ Substrate concentrations were 100 fold above the $K_{\mathrm{m}}$ for tryptamine and 50 fold above the $K_{\mathrm{m}}$ value for secologanin substrate as measured at $\mathrm{pH}$ 6.8. In this analysis, we make the assumption that the $K_{\mathrm{m}}$ values for the enzyme do not change significantly over the $\mathrm{pH}$ range measured and that the ternary complex is still accessible to proton transfer with the solution. Although the $\mathrm{pH}$ dependence of strictosidine synthase has previously been measured, ${ }^{16,18}$ the $\mathrm{p} K_{\mathrm{a}}$ values corresponding to these changes in enzyme activity have not been reported. We therefore measured the rate of strictosidine synthase in a series of buffers at fixed ionic strength under saturating substrate concentrations. Loss of activity at both acidic and basic $\mathrm{pH}$ values was observed (Figure 4). Fit of these data to a diprotic model suggested $\mathrm{p} K_{\mathrm{a}}$ values of two ionizable species at 4.70 and 8.28 . 
At $V_{\max }$ conditions, it is generally assumed that rate is limited by chemical catalysis and product release. A primary ${ }^{\mathrm{D}} V$ effect indicates that the chemistry of the reaction is significantly rate-controlling in comparison to product release. To verify that the chemistry (not product release) remained rate limiting over the $\mathrm{pH}$ range, we also assayed $\mathbf{1 b}$ to verify the presence of the primary KIE over the $\mathrm{pH}$ range (Figure 4). ${ }^{\mathrm{D}} V$ decreased somewhat at acidic $\mathrm{pH}$, and this effect may be due to contributions from either rate-limiting product release or from another mechanism. Although the existence of this effect hampers exact assignment of the lower $\mathrm{p} K_{\mathrm{a}}$ value, the significant primary isotope effect does indicate that the residue titrated at low $\mathrm{pH}$ is a catalytic species having a $K_{\mathrm{a}}$ value of approximately 4.6. Circular dichroism (CD) spectroscopy suggested that the protein secondary structure was unchanged at basic and acidic $\mathrm{pH}$ values (data not shown), although $\mathrm{CD}$ spectroscopy does not provide a detailed picture of the protein structure.

Although other effects, such as structural perturbations, may contribute to the reduced activity of strictosidine synthase at extreme $\mathrm{pH}$ values, Glu309, an amino acid with a $\mathrm{p} K_{\mathrm{a}}$ of approximately 4.5 , has been demonstrated to be critical for activity as evidenced by sitedirected mutagenesis (900-fold drop in $V_{\max }$ for Glu309Ala), ${ }^{14,19}$ indicating that this residue is important in the catalytic mechanism. The assignment of the basic $\mathrm{p} K_{\mathrm{a}}$ value, assuming that the loss of enzyme activity represents a change in ionization state of a catalytically important functional group, is less straightforward. The active site of the enzyme is largely hydrophobic, with only the residues Tyr151, His 307, and Glu309 located near the binding pocket. ${ }^{14}$ Mutation of the tyrosine residue (expected $\mathrm{p} K_{\mathrm{a}}$ in solution is 10 ) to phenylalanine results in only a small drop in $k_{\text {cat }}$ ( $78 \mathrm{~min}^{-1}$ for wild type to $58 \mathrm{~min}^{-1}$ for Tyr151Phe), suggesting that this residue does not play a critical role in acid-base catalysis. ${ }^{14}$ Mutation of His307 (typical $\mathrm{p} K_{\mathrm{a}}$ within an enzyme active site is $\left.5.5-7\right)^{24}$ reduces the $k_{\text {cat }}$ value by approximately 40 fold, significantly less than the 900 -fold decrease observed with the Glu309Ala mutant. ${ }^{14}$ This histidine residue appears to be over $4 \AA$ away from the amino group of the bound tryptamine, and over $5 \AA$ from the aldehyde oxygen of secologanin; thus, it is concluded from analysis of the crystal structure that this residue is not optimally positioned for a direct role in catalysis. ${ }^{14}$ No ordered water molecules appear in the enzyme structure, suggesting that these ionizable residues do not play a role in polarizing water molecules for catalysis. It is possible that the $\mathrm{p} K_{\mathrm{a}}$ value may be represented by the tryptamine substrate, suggesting that the protonation state of tryptamine plays a role in catalysis. Although the $\mathrm{p} K_{\mathrm{a}}$ of tryptamine is 10.2 in aqueous media, ${ }^{52}$ the $\mathrm{p} K_{\mathrm{a}}$ of a primary amine may be observed at 7.5-10.5 in the low dielectric environment of an enzyme binding pocket. ${ }^{24}$ However, since the rate-controlling step occurs well after alkylation of the primary amine, it is not clear that an effect on this moiety would be observed in the $\mathrm{pH}$ dependence of $V$. It is also possible that the $\mathrm{p} K_{\mathrm{a}}$ value of 8.3 is representative of the iminium intermediate; under basic conditions, the iminium could be deprotonated, thereby preventing electrophilic attack by the indole (step 4, Figure 1). In short, the $\mathrm{pH}$ profile data strongly suggest that an acidic residue is important for catalysis, and these data are supported by sitedirected mutagenesis studies implicating Glu309 in the mechanism. The meaning of the basic $\mathrm{p} K_{\mathrm{a}}$ value is less clear, since no obvious basic amino acid appears to be involved in the mechanism.

\subsubsection{Isotope Effects in the Nonenzymatic Pictet-Spengler Reaction-The}

Pictet-Spengler reaction occurs nonenzymatically in acidic media and is, in fact, an important reaction in organic synthesis. ${ }^{8}$ Surprisingly, to the best of our knowledge, isotope effects have not been reported for the Pictet-Spengler reaction under nonenzymatic conditions. The closest analogous system is the report of primary isotope effects between 2 and 3 for coupling of $\left[2-{ }^{2} \mathrm{H}\right]-3$-methyl-indole with electrophilic $p$-nitrobenzenediazonium ion at $30{ }^{\circ} \mathrm{C} .{ }^{45}$ Therefore, to provide a context for our observed enzymatic ${ }^{\mathrm{D}} V$ of 2.67 , we studied a model Pictet-Spengler reaction in solution. 
Acetic acid (AcOH), with a $\mathrm{p} K_{\mathrm{a}}$ value similar to that of the glutamate residue implicated in enzymatic catalysis, was used to buffer the reaction under mild, aqueous reaction conditions. We found the ester of secologanin is hydrolytically labile on the slower time scale of solution kinetics, and thus the model aldehyde propanal 4 (Figure 1) was used in these experiments. As assayed by HPLC, the equilibrium constant was less than 1, and excess aldehyde or tryptamine was required to drive the reaction to completion. Kinetic analysis was complicated by the presence of an intermediate that was eventually consumed by the end of the reaction. Isolation and structural analysis suggested that this intermediate was a carbinolamine resulting from condensation of aldehyde with the indole nitrogen (Supporting Information). When isolated by preparative HPLC, the intermediate decomposed cleanly to tryptamine and aldehyde. Therefore, it was simply treated as a reversible, nonproductive intermediate for estimation of rate constants (see Materials and Methods). No other intermediates were detectable by HPLC, LC-MS, or NMR. Attempts to trap intermediates by reductive amination led to complex mixtures consisting primarily of over-alkylated product (data not shown).

The kinetic behavior of the reaction of tryptamine $1 \mathrm{a} / \mathrm{b}$ and propanal 4 in solution was surveyed in a variety of $\mathrm{pH}$ values, buffers, and substrate concentrations using an HPLC assay (see Figure S11, Supporting Information). As expected, the Pictet-Spengler reaction was first order in both reactants. The apparent KIE for the reaction under these varied conditions ranged from 2.0 to 2.6, indicating that deprotonation (Figure 1, step 5) is at least a partially rate-controlling step in both the solution and enzymatic reactions and the expression of the KIE is sensitive to the reaction conditions.

\subsubsection{The Role of General Acid-Base Catalysis in the Pictet-Spengler}

Reaction-Electrophilic aromatic substitution reactions that exhibit primary isotope effects are base catalyzed. ${ }^{44}$ However, the Pictet-Spengler reaction is generally carried out under acidic conditions. To understand the role of acid-base catalysis in the mechanism, we examined the dependence of the primary KIE on the solution reaction conditions in more detail. The apparent rate constant $k_{\text {obs }}$ (eq 5) was measured for several $\mathrm{pH}$ values between 4 and 5 in acetic acid buffers of constant ionic strength for reaction of propanal 4 with tryptamine $\mathbf{1 a}$ and $\left[2{ }^{2} \mathrm{H}\right]$-tryptamine $\mathbf{1 b}$ (Figure S10, Supporting Information). These data revealed that the overall rate of the reaction is increased by the presence of acid. Therefore, although the primary rate-controlling step [deprotonation (Figure 1, step 5)] is basecatalyzed, the overall Pictet-Spengler reaction is apparently acid catalyzed.

observed rate $=k_{\mathrm{obs}}[$ tryptamine 1$][$ propanal 4]

We further noted that as the $\mathrm{pH}$ was kept constant, the reaction rate increased with concentration of the acetate buffer $(\mathrm{AcOH})$, suggesting that the reaction is also catalyzed by buffer. We combined these two factors, $\mathrm{pH}$ and buffer concentration, by considering the reaction rate as a function of protonated buffer $[\mathrm{AcOH}](\mathrm{eq} 6)$. $[\mathrm{AcOH}]$ was calculated from the literature $\mathrm{p} K_{\mathrm{a}}$ value 52 adjusted for ionic strength, the measured $\mathrm{pH}$, and known buffer concentration (Materials and Methods). When $k_{\mathrm{obs}}$ was plotted against [AcOH], a linear dependence in rate was observed (Figure 5A). Such a linear dependence was not observed for $\left[\mathrm{AcO}^{-}\right]$concentration. In this aqueous model reaction, the rate does not appear to be linearly dependent on $\mathrm{pH}$ but on protonated buffer, AcOH. Therefore the Pictet-Spengler reaction under aqueous acidic conditions obeys general acid catalysis. 


$$
k_{\mathrm{obs}}=k_{\mathrm{HA}}[\mathrm{AcOH}]+k^{\prime}
$$

Since isotope effects reveal that a base-catalyzed step, deprotonation, is rate limiting, we introduced general base catalysis by acetate ion $\mathrm{AcO}^{-}$to eq 6 in the form of eq 7. In this equation, $k_{\mathrm{o}}$ represents non-buffer-mediated catalysis (catalysis by solvent $\mathrm{H}_{2} \mathrm{O}$ and $\mathrm{H}^{+}$) for each sample in Figure 5A. To determine $k_{\mathrm{HA}}$ and $k_{\mathrm{A}}$ in eq 7, the rate constants in Figure 5A were corrected for $k_{\mathrm{O}}$ and plotted against the fraction of protonated acetic acid buffer, a continuum from $\mathrm{AcO}^{-}$to $\mathrm{AcOH}$ (see Materials and Methods), graphically revealing the effects of the acidic and basic species on the KIE. It was found that the KIE extrapolated to 1 as $[\mathrm{AcOH}]$ approached zero (Figure $5 \mathrm{~B}$ ). Conversely, as $[\mathrm{AcOH}]$ increased and $\left[\mathrm{AcO}^{-}\right]$ decreased, the KIE reached a maximum value of $2.65 \pm 0.10$. By considering the expression of the KIE as a mechanistic probe, we hypothesize that in the absence of general acid, the acid-catalyzed step becomes rate-controlling. Therefore, the deprotonation step is no longer rate limiting, and the primary KIE is no longer observed.

$$
k_{\mathrm{obs}}=k_{\mathrm{HA}}[\mathrm{AcOH}]+k_{\mathrm{A}}\left[\mathrm{AcO}^{-}\right]+k_{\mathrm{o}}
$$

Two possible steps may account for the apparent acid catalysis. Acid could be required to

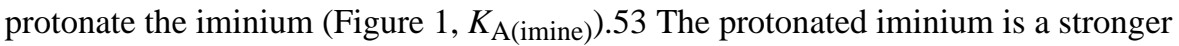
electrophile than the imine and is therefore a better substrate for cyclization (Figure 1, step 4). Another candidate for the acid-catalyzed step is protonation of the carbinolamine involved in the formation of the iminium species (Figure 1, step 3). ${ }^{53}$ To distinguish between these possibilities, $N$ - $\omega$-methyltryptamine 5 (Figure 1) was reacted with propanal 4 in the same acetic acid buffers used for buffer dependence studies with tryptamine $\mathbf{1 a}$ and $\left[2-^{2} \mathrm{H}\right]$-tryptamine $\mathbf{1 b}$. The iminium resulting from reaction of this secondary amine with aldehyde is charged and electrophilic, independent of acid. Therefore, if protonation of the neutral imine species limited available electrophile (Figure $1, K_{\mathrm{A}(i m i n e)}$ ), then the acid catalysis observed with tryptamine $\mathbf{1 a}$ and $\mathbf{1 b}$ should be abolished with $\mathbf{5}$. However, the reaction with $\mathbf{5}$ displays the same dependence on general acid as tryptamine $\mathbf{1 a}$ and $\mathbf{1 b}$ (Figure S12, Supporting Information), leaving protonation of the carbinolamine as the most likely rate-controlling step.

3.2.4. Comparison of Solution and Enzymatic Reactions-Primary KIEs between 2 and 3 have often been reported for electrophilic aromatic substitution reactions; ${ }^{43}$ theoretical explanations for these relatively small values have been reviewed. ${ }^{44}$ However, in the case of the Pictet-Spengler reaction, the presence of a second rate-controlling step additionally limits full expression of the intrinsic primary KIE. The steps of iminium formation and $\beta$-carboline formation have opposite catalytic requirements; under conditions when the acid-catalyzed step is faster, the base-catalyzed step becomes more rate limiting. Given the presence of two competing steps, our extrapolated maximal KIE of 2.7 in the nonenzymatic reaction describes the conditions at which the final deprotonation is most rate controlling and the protonation of carbinolamine step is relatively fast.

The observed enzymatic KIE ${ }^{\mathrm{D}} V$ of 2.7 at the optimal $\mathrm{pH}$ of the enzymatic reaction (pH 7) is a close match to the maximal KIE observed in the nonenzymatic reaction. These similar magnitudes suggest that the enzyme primarily catalyzes the first, acid-catalyzed rate-limiting step of iminium formation. Steric differences between propanal $\mathbf{4}$ and secologanin $\mathbf{2}$ do not appear to significantly influence the KIE since a variety of aldehydes gave similar KIE values for solution reactions (data not shown). Nonchemical steps often contribute to 
reduced expression of KIEs in enzymes. ${ }^{50}$ Given our current understanding of the solution Pictet-Spengler reaction, the expression of a significant KIE for deuterium substitution at the 2-position of tryptamine indicates that the enzyme efficiently catalyzes carbinolamine protonation.

Therefore, we propose that tryptamine $\mathbf{1}$ enters the active site with the primary amine within hydrogen-bonding distance to Glu309, as suggested by the crystal structure (2FPB) (Figure 2). Tryptamine $\mathbf{1}$ is most likely protonated under the conditions of the assay $(\mathrm{pH} 7)$ and, after entering the active site, transfers its proton to deprotonated Glu309. This proton transfer is consistent with the orientation of tryptamine relative to Glu309 in the crystal structure, and the importance of the tryptamine protonation state to the mechanism is consistent with the loss of enzyme activity at basic $\mathrm{pH}$. After transferring a proton to Glu309, tryptamine would then be nucleophilic enough to attack the aldehyde substrate to rapidly generate the carbinolamine species (Figure 1, step 2). The protonated Glu309 could then act as the general acid that is required to protonate the carbinolamine and catalyze the formation of the iminium species through loss of water (Figure 1, step 3). Given that there are no other ionizable residues in the vicinity (Figure 2), we propose that the newly deprotonated Glu309 (like acetate in the solution reaction) could also catalyze the ratelimiting deprotonation step (Figure 1, step 5; Figure 2).

Strictosidine synthase catalyzes iminium formation, which can be rate limiting in solution. The enzyme acts as a scaffold to increase the local concentrations of the tryptamine, aldehyde, and acid catalyst species. To qualitatively provide a sense of how important this effect is, we compared the rate laws for the solution (nonenzymatic) reaction with acetic acid catalyst and propanal substrate $4\left(\mathrm{rate}=\left(6.25 \times 10^{-4} \mathrm{M}^{-2} \mathrm{~s}^{-1}\right)[\mathrm{AcOH}]\right.$ [aldehyde] [tryptamine]) with a previously reported rate law for the enzymatic reaction at $V_{\max }$ (rate $=$ $\left(1.67 \mathrm{~s}^{-1}\right)$ [enzyme]). ${ }^{19}$ Setting the concentrations of the catalysts to an arbitrary concentration of $1 \mathrm{M}$, these rate laws become $\left(6.25 \times 10^{-4} \mathrm{M}^{-1} \mathrm{~s}^{-1}\right)$ [aldehyde][tryptamine] and $\left(1.67 \mathrm{M} \mathrm{s}^{-1}\right)$, respectively. Setting these equal to each other yields [aldehyde] [tryptamine] $=2.7 \times 10^{3} \mathrm{M}^{2}$. Assuming that the local concentrations of each reactant are equal, this analysis gives an equivalent concentration of $52 \mathrm{M}$ for each reactant in the enzyme active site to achieve a rate equal to that of the acid-catalyzed solution reaction. This qualitative analysis suggests that increasing the local concentration of substrates and catalytic acid group to promote rapid iminium formation is a major mechanism of rate acceleration in strictosidine synthase. The similar KIE values imply that the relative rates of the two rate-controlling steps are similar in solution and enzyme-catalyzed reactions. Therefore, to a first approximation, strictosidine synthase does not appear to catalyze electrophilic aromatic substitution any more than would be expected by an increased local concentration of reactive species.

\subsubsection{Cocrystallization of Strictosidine Synthase with a Bisubstrate Inhibitor}

-A key difference between the enzyme-catalyzed and solution reaction is that strictosidine synthase not only increases the local concentration of substrates but also acts as a scaffold to appropriately orient the imnium intermediate as it undergoes cyclization to produce a diastereoselective product (Figure 1, step 4). While the KIE data, the $\mathrm{pH}$ dependence of the rate, and the model solution reaction described above can be used to make mechanistic predictions about steps 3 and 5 (Figure 1), these data do not provide any insight into step 4, which is when this key stereocenter is set. Step 4 of the Pictet-Spengler reaction using indole amine substrates also has an additional complication. These reactions have been proposed to proceed through a spiroindolenine intermediate resulting from attack from the 3-position (Figure 1, steps 4a and 4b), ${ }^{13}$ although direct attack by the 2-position (Figure 1, step 4) also appears to contribute to the mechanism. ${ }^{12,54,55}$ It is not clear which mechanism 
would be favored for the enzyme. For all of these reasons, we wished to further examine step 4 in detail.

Structural analysis could provide insights into the model of binding of the imine as it is oriented relative to carbons 2 and 3 during the cyclization step. However, the imine intermediate is not sufficiently stable for cocrystallization with strictosidine synthase. Therefore, we synthesized the reductive amination product of tryptamine 1a and secologanin $\mathbf{2}$, compound $\mathbf{6}$, with a flexible amine linkage between the indole and secologanin moieties which could approximate the conformation of the iminium. We demonstrated that $\mathbf{6}$ is a potent inhibitor of strictosidine synthase with an $\mathrm{IC}_{50}$ value of $3 \pm 0.5 \mathrm{nM}$ (Figure $6 \mathrm{~A}$ ).

Inhibitor 6 readily cocrystallized with strictosidine synthase (R. serpentina), and structural data of the complex were obtained at $3 \AA$ resolution. However, the electron density suggested that the indole of $\mathbf{6}$ was bound in a different conformation compared to the conformation when tryptamine alone was bound to strictosidine synthase (2FPB) (Figure $6 \mathrm{~B})$. In contrast, the secologanin moiety of the inhibitor overlaid well with the previously reported enzyme-secologanin complex (Figure 6B). The conformation of the inhibitor that was suggested by the electron density was not representative of a productive cyclization state; neither carbon $2(4.78 \AA$ ) or $3(3.86 \AA)$ of the inhibitor was positioned close to the atom that corresponded to the electrophilic iminium carbon (Figure 6C). These crystallography data suggest that the tryptamine binding pocket can allow binding modes that are not conducive to Pictet-Spengler cyclization. We suspect that the rigidity of the $\mathrm{sp}^{2}$ hybrized iminium moiety is critical for fostering a productive binding orientation that can lead to cyclization, and that the more flexible $\mathrm{sp}^{3}$ hybridized amine of the inhibitor can adopt conformations inaccessible to the iminium intermediate.

3.2.6. Theoretical Calculations-Since structural analyses did not provide insight into the orientation of the iminium involved in the cyclization step, we turned to theoretical models of the transition states on the pathway to step 4 (Figure 1). Ab initio calculations were used to model the transition states of both the spiroindolenine (Figure 1, step 4a) and the six-membered ring (Figure 1, step 4) intermediates, and the free energies of these transition states were compared to predict the favored mechanism (Figure 7). Free energies were computed relative to the trans form of the iminium species, the lowest-energy groundstate structure according to the calculations. To facilitate computational analysis, instead of secologanin 2, the calculations were performed with a simplified structure (Figure 7; $\mathrm{R}=\mathrm{Me}$ in Figure 1). For both 2-attack (Figure 1, step 4) and 3-attack (Figure 1, step 4a), eight different transition states were found which link either trans- or cis-iminium species with either five-or six-membered rings via attack with the R-group oriented either "over" or "off" of the initial ring during the attack (Figure 7). All transition-state species had a single imaginary frequency, and the vibrational contribution to the free energy was included at 300 K. Figure 7 shows the free energies of the stable species and the lowest-energy transition states required to connect the network of stable species. Transition states below a free energy on the left axis are accessible from the trans-iminium species on the corresponding time scales given on the right-axis. Transition states of higher energy than the five shown provide redundant connections in the network, and thus they have been omitted for clarity (see Supporting Information for the other transition-state structures).

The calculations indicate that interconversion from the iminium (both cis and trans forms) directly to a six-membered ring by 2 -attack is several orders of magnitude faster than interconversion from cis- or trans-iminium to five-membered ring spiroindolenines. This suggests that the spiroindolenine intermediate is more rarely visited in the mechanism. Furthermore, transition-state searches for the 1,2-shift between the six-membered ring and the spiroindolenine searches repeatedly resulted in transition states leading back to the 
iminium species. For configurations that lie between the spiroindolenine and the sixmembered ring, the calculations suggest that electron density easily shifts from the migrating carbon to the nitrogen, resulting in increased $\mathrm{sp}^{2}$ character at the migrating carbon center. Our results suggest, but do not prove, the 1,2-shift does not occur and that the spiroindolenine only rearranges to reform the imnium species. However, the availability of a lower-energy pathway from the iminium to a six-membered ring relative to the iminiumspiroindolenine pathways suggests that, if a 1,2-shift does exist, it would not significantly contribute to the mechanism.

These results are consistent with the empirical rule that 6-endo-ring closures are favored over 5-endo-trig cyclizations. Moreover, the stereospecificity of the Pictet-Spengler reaction can be rationalized by considering a direct attack mechanism from the 2-position. ${ }^{56}$ Finally, the $a b$ initio results confirm previous conclusions of Kowalski et al. Their semiempirical calculations did find a transition state for the 1,2-shift, but it was of significantly higher energy than the transition state for a direct 2-attack. ${ }^{12,55}$ Notably, direct evidence for formation of the spiroindolenine intermediate by isotopic scrambling has been observed with several indole substrates. ${ }^{10,11,13,57}$ There is only an $8 \mathrm{kcal} / \mathrm{mol}$ barrier to form the spiroindolenine intermediate, so that if deprotonation (Figure 1, step 5) is slower than $k T / h$ $\mathrm{e}^{(-8 / k T)}$, accessing the spiroindolenine during the course of the reaction could reasonably be expected to occur. Interestingly, the free energy landscape shows that the spiroindolenine (structure G, Figure 7) provides a relatively low-energy pathway for interconversion of cisand trans-iminium isomers. The calculations however, suggest that the 1,2-shift from the spiroindolenine to form the six-membered ring (Figure 1, step 4b) does not occur; thus, access to the spiroindolenine is an unproductive step in the Pictet-Spengler mechanism. Therefore, while step $4 \mathrm{a}$ in Figure 1 is accessible-though less energetically favorable than step 4-step 4b does not appear to be accessible.

\section{Summary}

Strictosidine synthase stereoselectively constructs the central alkaloid biosynthetic intermediate strictosidine 3. The Pictet-Spengler reaction also occurs in solution, although without the presence of a chiral catalyst the reaction is not stereoselective. ${ }^{58,59}$ Several strategies were undertaken to probe the mechanism of this enzymatic Pictet-Spengler reaction. First, a primary KIE value was measured for both the enzymatic and solution Pictet-Spengler reactions. The magnitude of the enzymatic KIE was similar to the KIE measured for the solution reaction catalyzed by acetic acid in the absence of solvent water catalysis $\left(k_{\mathrm{HA}}\right.$, Figure $\left.5 \mathrm{~B}\right)$. Therefore, deprotonation to form the final product (Figure 1, step 5) appears to be rate controlling in both solution and in the enzyme active site. Although we initially expected cyclization to be rate controlling (Figure 1, step 4), previously reported studies of electrophilic aromatic substitution suggest that, as the rate of the reverse reaction increases relative to the rate of deprotonation, the deprotonation becomes rate controlling, and a large KIE is observed. ${ }^{43,44}$

Interestingly, a primary KIE has been observed for the Pictet-Spengler reaction catalyzed by norcoclaurine synthase, an enzyme that utilizes a dopamine substrate instead of tryptamine 1a. ${ }^{60}$ This suggests that deprotonation is also rate controlling in enzymatic Pictet-Spengler reactions that utilize non-indole substrates. The authors speculated that norcoclaurine synthase changes the rate-controlling step of the reaction, and that rearomatization (i.e., Figure 1, deprotonation step 4) is not rate controlling for nonenzymatic catalyzed reactions. However, our nonenzymatic reactions show that, at least with indole amine substrates, deprotonation is, in fact, rate controlling in the solution Pictet-Spengler reaction, provided that a general acid is available to ensure that iminium formation is rapid. 
While the rate-controlling step of deprotonation is base-catalyzed, the dependence of the solution reaction on $\mathrm{pH}$ and buffer concentration suggests that the overall Pictet-Spengler reaction is general acid-catalyzed. Based on the observed $\mathrm{p} K_{\mathrm{a}}$ values calculated from the $\mathrm{pH}$ dependence curve of enzymatic rate (Figure 4), the known residues surrounding the tryptamine 1a and secologanin 2 binding sites, and previously reported site-directed mutagenesis studies, ${ }^{14}$ Glu309 appears to be the only residue available for acid-base catalysis. Therefore, Glu309 likely plays the role of general acid catalyst in strictosidine synthase. A number of possible ionizable groups, including the tryptamine substrate or iminium intermediate, could account for the observed basic $\mathrm{pH}$ dependence.

Although little mechanistic data is available for enzymatic Pictet-Spengler catalysis, enzymatic iminium formation-the first part of the Pictet-Spengler reaction-has been well studied in enzymes such as aldolases, acetoacetonate decarboxylase, pyridoxal- and pyruvate-containing decarboxylases, and dehy-dratases. ${ }^{53}$ Imine formation is a two-step process involving addition of an amine to form a carbinolamine followed by dehydration to the imine (Figure 1, steps 2-3). In these enzymes, it is proposed that a catalytic residue, often a glutamic acid ${ }^{61,62}$ or an ordered water molecule ${ }^{63}$ protonates the carbino-lamine to catalyze dehydration to the iminium species. An ordered active-site water molecule does not appear to be present in the crystal structure of strictosidine synthase.

With the current evidence, we propose that Glu309 is responsible for protonation of the carbinolamine and that the resulting iminium formation is the key acid-catalyzed step of the Pictet-Spengler reaction (Figure 8). Protonated tryptamine can enter the active site and transfer its proton to Glu309, thereby supplying the proton for acid-catalysis (Figure 8). No acid-base catalysis is required for the cyclization step during which the stereocenter is formed (Figure 8), and it is likely that the enzyme holds the iminium intermediate in the appropriate conformation to achieve the correct diastereomer after cyclization. The nonproductive conformation of a flexible bisubstrate inhibitor 6 bound in the enzyme crystal structure suggests that the enzyme also relies on the relatively rigid $\mathrm{sp}^{2}$ hybridized iminium to ensure this intermediate is in a correct conformation for cyclization (Figure 1, step 4). $A b$ initio calculations were used to provide insight into this step of the mechanism. Energy levels of theoretically predicted transition states suggest that the transition state leading to the spiroindolenine intermediate is higher in energy than the transition state resulting from direct 2-attack. Moreover, since ab initio calculations suggest that the 1,2-alkyl rearrangement of the spiroindolenine does not occur, if the spiroindolenine is formed, it is most likely an unproductive intermediate (Figure 8). It is difficult to predict which face of attack from the indole is most favored by the constraints of the enzyme active site. To facilitate the ab initio calculations, the structures of the calculated transition states lacked the secologanin moiety; the absence of this group complicated attempts to accurately dock the calculated structures into the active site. Additionally, the structure of the enzyme-inhibitor 6 complex illustrates that the indole moiety can bind in the active site in more than one orientation, which further complicated docking efforts. We speculate, although cannot prove, that strictosidine synthase would be likely to favor one of the lower-energy transition states. For example, if formation of the trans-iminium isomer is catalyzed by the enzyme, then structure D (Figure 7) would be a likely transition state. Additional bisubstrate inhibitors with different linkages between the secologanin and tryptamine moieties may crystallize in a "productive" conformation that could be compared and overlaid with the calculated structures.

It is possible that Glu309 is also responsible for the final deprotonation step, since there do not appear to be any other appropriate residues to perform this role (Figure 8). Glu309 is near carbon 2 of tryptamine 1a as measured from the crystal structure of the enzyme- 
tryptamine complex 2FPB (see Figure 2, green line, 3.2 $⿱$ ) ). Also, the careful kinetic analysis in Figure 4B indicates that a carboxylate ion is sufficient to catalyze deprotonation $\left(k_{\mathrm{A}}\right)$.

Although the Pictet-Spengler reaction can occur spontaneously in solution, an enzymatic catalyst is always utilized in alkaloid biosynthesis. This is partly due to the fact that very little reaction would occur on a reasonable time scale at the low (submillimolar) concentrations of secologanin and tryptamine substrates in $-i-o$. Additionally, strictosidine synthase also ensures that a single diastereomer is produced for subsequent biosynthetic steps; notably, the R diastereomer of strictosidine (vincoside), formed in approximately $60 \%$ yield in the solution reaction (Figure S9A, Supporting Information) is not incorporated into downstream monoterpene indole alkaloids. ${ }^{64}$ The mechanistic studies reported here strongly suggest that strictosidine synthase does not significantly alter the mechanism of the reaction as it occurs in solution under conditions of rapid iminium formation. Notably, the PictetSpengler cyclization is an example of an electrophilic aromatic substitution reaction where the final deprotonation step is rate controlling, provided that formation of the iminium is fast. The strictosidine synthase catalyst has evolved to arrange the amine and aldehyde substrates, along with a general acid-base catalyst, in high local concentration to achieve efficient catalysis.

Data deposition: The atomic coordinates and structure factors have been deposited in the Protein Data Bank, www.pdb.org (PDB ID code 2VAQ [PDB], R2VAQSF (SRUCTURE FACTORS)).

\section{Supplementary Material}

Refer to Web version on PubMed Central for supplementary material.

\section{Acknowledgments}

Financial support was provided from MIT to S.E.O. L.A.G. is supported by Ford Foundation and NSF predoctoral fellowships. A.F. was supported by Deutscher Akademischer Austausch Dienst (German Academic Exchange Service). Deutsche Forschungsgemeinschaft (Bonn, Bad-Godesberg, Germany) to J.S. and S.P. Research was also supported by the European Community (Research Infrastructure Action under the FP6 "Structuring the European Research Area Programme" contract No. RII3/CT/2004/5060008). The Biophysical Instrumentation facility (NSF-0070319 and GM68762), the Chemistry Instrumentation Facility (NIH 1S10RR015926), and the MIT/ Harvard Center for Magnetic Resonance (NIH EB-002026) at MIT are gratefully acknowledged. We gratefully acknowledge Joseph Gregg for assistance in the preparation of inhibitor 6.

\section{References}

1. De-Eknamkul W, Suttipanta N, Kutchan TM. Phytochemistry. 2000; 55:177-181. [PubMed: 11065292]

2. Samanani N, Liscombe DK, Facchini PJ. Plant J. 2004; 40:302-313. [PubMed: 15447655]

3. Minami H, Dubouzet E, Iwasa K, Sato F. J Biol Chem. 2007; 282:6274-6282. [PubMed: 17204481]

4. McKnight TD, Roessner CA, Devagupta R, Scott AI, Nessler C. Nucleic Acids Res. 1990; 18:4939. [PubMed: 2395663]

5. Kutchan TM, Hampp N, Lottspeich F, Beyreuther K, Zenk MH. FEBS Lett. 1988; 237:40-44. [PubMed: 3049153]

6. Van der Heijden R, Jacobs DI, Snoeijer W, Hallard D, Verpoorte R. Curr Med Chem. 2004; 11:607628. [PubMed: 15032608]

7. O'Connor SE, Maresh J. Nat Prod Rep. 2006; 23:532-547. [PubMed: 16874388]

8. Cox ED, Cook JM. Chem Rev. 1995; 95:1797-1842.

9. Pictet A, Spengler T. Ber Dtsch Chem Ges. 1911; 44:2030-2036.

10. Bailey PD. J Chem Res, Synop. 1987:202-203. 
11. Ibaceta-Lizana JS, Jackson AH, Prasitpan N, Shannon PVR. J Chem Soc, Perkin Trans II. 1987:1221-1226.

12. Kowalski P, Mokrosz JL. Bull Soc Chim Belg. 1997; 106:147-149.

13. Ungemach F, Cook JM. Heterocycles. 1978; 9:1089-1119.

14. Ma X, Panjikar S, Koepke J, Loris E, Stockigt J. Plant Cell. 2006; 18:907-920. [PubMed: 16531499]

15. Mizukami H, Nordlov H, Lee SL, Scott AI. Biochemistry. 1979; 18:3760-3763. [PubMed: 476085]

16. Treimer JF, Zenk MH. Eur J Biochem. 1979; 101:225-233. [PubMed: 510306]

17. Pfitzner U, Zenk MH. Planta Med. 1989; 55:525-530. [PubMed: 17262473]

18. de Waal A, Meijer AH, Verpoorte R. Biochem J. 1995; 306:571-580. [PubMed: 7887913]

19. Bernhardt P, O’Connor SE. Chem Biol. 2007; 14:888-897. [PubMed: 17719488]

20. McCoy E, Galan MC, O’Connor SE. Bioorg Med Chem Lett. 2006; 16:2475-2478. [PubMed: 16481164]

21. Northrop DB. Anal Biochem. 1983; 132:457-461. [PubMed: 6625178]

22. Ellis KJ, Morrison JF. Methods Enzymol. 1982; 87:405-426. [PubMed: 7176924]

23. Holtzhauer, M. Basic Methods for the Biochemical Lab. Springer-Verlag; Heidelberg, Germany: 2006. Buffers: Theoretical Considerations; p. 191-197.

24. Cleland, WW. Advances in Enzymology and Related Areas of Molecular Biology. Meister, A., editor. Vol. 45. John Wiley \& Sons; New York: 1977. p. 320-348.

25. Cook, PF.; Cleland, WW. Enzyme Kinetics and Mechanism. Garland Science; New York: 2007. p. 325-366.

26. Mendes P. Trends Biochem Sci. 1997; 22:361-3630. [PubMed: 9301339]

27. Matsuda SPT, Wilson WK, Xiong Q. Org Biomol Chem. 2006; 4:530-543. [PubMed: 16446812]

28. Peters B, Heyden A, Bell AT, Chakraborty A. J Chem Phys. 2004; 120:7877-7886. [PubMed: 15267702]

29. Tomasi J, Persico M. Chem Rev. 1994; 94:2027-2094.

30. Ma XY, Koepke J, Fritzsch G, Diem R, Kutchan TM, Michel H, Stöckigt J. Biochem Biophys Acta. 2004; 1702:121-124. [PubMed: 15450856]

31. Otwinowski Z, Minor W. Methods Enzymol. 1997; 276:307-326.

32. Panjikar S, Parthasarathy V, Lamzin VS, Weiss MS, Tucker PA. Acta Crystallogr, Sect D. 2005; 61:449-457. [PubMed: 15805600]

33. Vagin A, Teplyakov A. J Appl Crystallogr. 1997; 30:1022-1025.

34. Brünger AT, Adams PD, Clore GM, DeLano WL, Gros P, Grosse-Kunstleve RW, Jiang JS, Kuszewski J, Nilges M, Pannu NS, Read RJ, LMR, Simonson T, Warren GL. Acta Crystallogr, Sect D. 1998; 54:905-921. [PubMed: 9757107]

35. Emsley P, Cowtan K. Acta Crystallogr, Sect D. 2004; 60:2126-2132. [PubMed: 15572765]

36. Murshudov GN, Vagin AA, Dodson EJ. Acta Crystallogr, Sect D. 1997; 53:240-255. [PubMed: 15299926]

37. Ramakrishnan C, Ramachandran GN. Biophys J. 1965; 5:909-933. [PubMed: 5884016]

38. Laskowski RA, MacArthur MW, Moss DS, Thornton JM. J Appl Crystallogr. 1993; 26:283-291.

39. Parkin, DW. Methods for the Determination of Competitive and Noncompetitive Kinetic Isotope Effects. In: Cook, PF., editor. Enzyme Mechanism from Isotope Effects. CRC Press: Boca Raton; 1991. p. 269-290.

40. Northrop DB. Biochemistry. 1981; 20:4056-4061. [PubMed: 7284308]

41. For enzyme reactions, isotope effects on the limiting macroscopic rate constants $V_{\max }$ and $V_{\max } /$ $K_{\mathrm{m}}$ are shortened to $\mathrm{D} V$ and $\mathrm{D}\left(V / K_{\mathrm{a}}\right)$ respectively (the subscript "a" indicates the varied substrate). For chemical reactions $k_{\mathrm{H}} / k_{\mathrm{D}}$ is simply $\mathrm{D} k$.

42. Jackson AH, Smith AE. Tetrahedron. 1968; 24:403-413.

43. Zollinger, H. Advances in Physical Organic Chemistry. Gold, V., editor. Vol. 2. Academic Press; London: 1964. p. 163-196. 
44. Berliner, E. Progress in Physical Organic Chemistry. Cohen, SG.; Streitweiser, A.; Taft, RW., editors. Vol. 2. Interscience; New York: 1964. p. 253-321.

45. Jackson AH, Lynch PP. J Chem Soc, Perkin Trans II. 1987:1483-1488.

46. Zollinger H. Helv Chim Acta. 1955; 38:1623-1631.

47. Zollinger H. Helv Chim Acta. 1955; 38:1617-1622.

48. Zollinger H. Helv Chim Acta. 1955; 38:1597-1616.

49. Northrop DB. J Chem Edu. 1998; 75:1153-1157.

50. Klinman JP, Matthews RG. J Am Chem Soc. 1985; 107:1058-1060.

51. Karsten, WE.; Cook, PF. Isotope Effects in Chemistry and Biology. Kohen, A.; Limbach, H-H., editors. Taylor \& Francis; Boca Raton: 2006. p. 793-809.

52. Perrin, DD. Dissociation Constants of Organic Bases in Aqueous Solution (and Supplement, 1972). Butterworths; London: 1965.

53. (a) Hupe DJ. New Compr Biochem. 1984; 6:271-301.(b) Jencks, WP. Catalysis in Chemistry and Enzymology. McGraw-Hill; New York: 1969.

54. Casnati G, Dossena A, Pochini A. Tetrahedron Lett. 1972:5277-5280.

55. Kowalski P, Bojarski AJ, Mokrosz JL. Tetrahedron. 1995; 51:2737-2742.

56. Li D, Czerwinski K, Cook JM. Tetrahedron Lett. 1991; 32:175-178.

57. Jackson AH, Smith P. Chem Commun. 1967; 128:264-266.

58. Seayad J, Seayad AM, List B. J Am Chem Soc. 2006; 128:1086-1087. [PubMed: 16433519]

59. Taylor MS, Jacobsen EN. J Am Chem Soc. 2004; 126:10558-10559. [PubMed: 15327311]

60. Luk LYP, Bunn S, Liscombe DK, Facchini PJ, Tanner ME. Biochemistry. 2007; 46:10153-10161. [PubMed: 17696451]

61. Lorentzen E, Siebers B, Hensel R, Pohl E. Biochemistry. 2005; 44:4222-4229. [PubMed: 15766250]

62. St-Jean M, Lafrance-Vanasse J, Liotard B, Sygusch J. J Biol Chem. 2005; 280:27262-27270. [PubMed: 15870069]

63. Fullerton SWB, Griffiths JS, Merkel AB, Cheriyan M, Wymer NJ, Hutchins MJ, Fierke CA, Toone EJ, Naismith JH. Bioorg Med Chem. 2006; 14:3002-3010. [PubMed: 16403639]

64. Heckendorf AH, Hutchinson CR. Tetrahedron Lett. 1977; 48:4153-4154. 


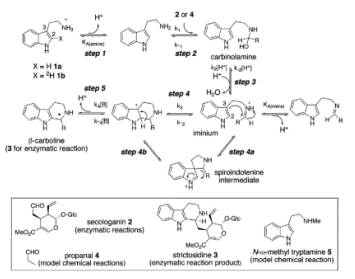

Figure 1.

Pictet-Spengler reaction mechanism. Substrates used in this study are shown. 


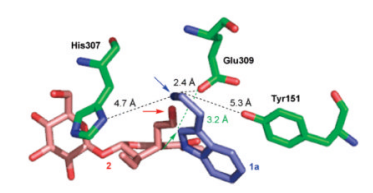

Figure 2.

Structure of strictosidine synthase active site, highlighting ionizable amino acids surrounding the tryptamine and secologanin. Crystal structure of enzyme complex with tryptamine (2FPB, $2.8 \AA$ A resolution) is overlaid with structure of secologanin (from 2FPC, 3.0 A resolution). The amine of tryptamine is highlighted with a blue arrow, and the aldehyde of secologanin is highlighted with a red arrow. Surrounding polar residues are shown in green. Distances from the amine of tryptamine to the surrounding amino acid side chains are shown. The $\mathrm{C} 2$ carbon of tryptamine is highlighted with a green arrow, and the distance from the carboxyl group of Glu309 to this carbon is also shown (3.2 $\AA$, green line). 

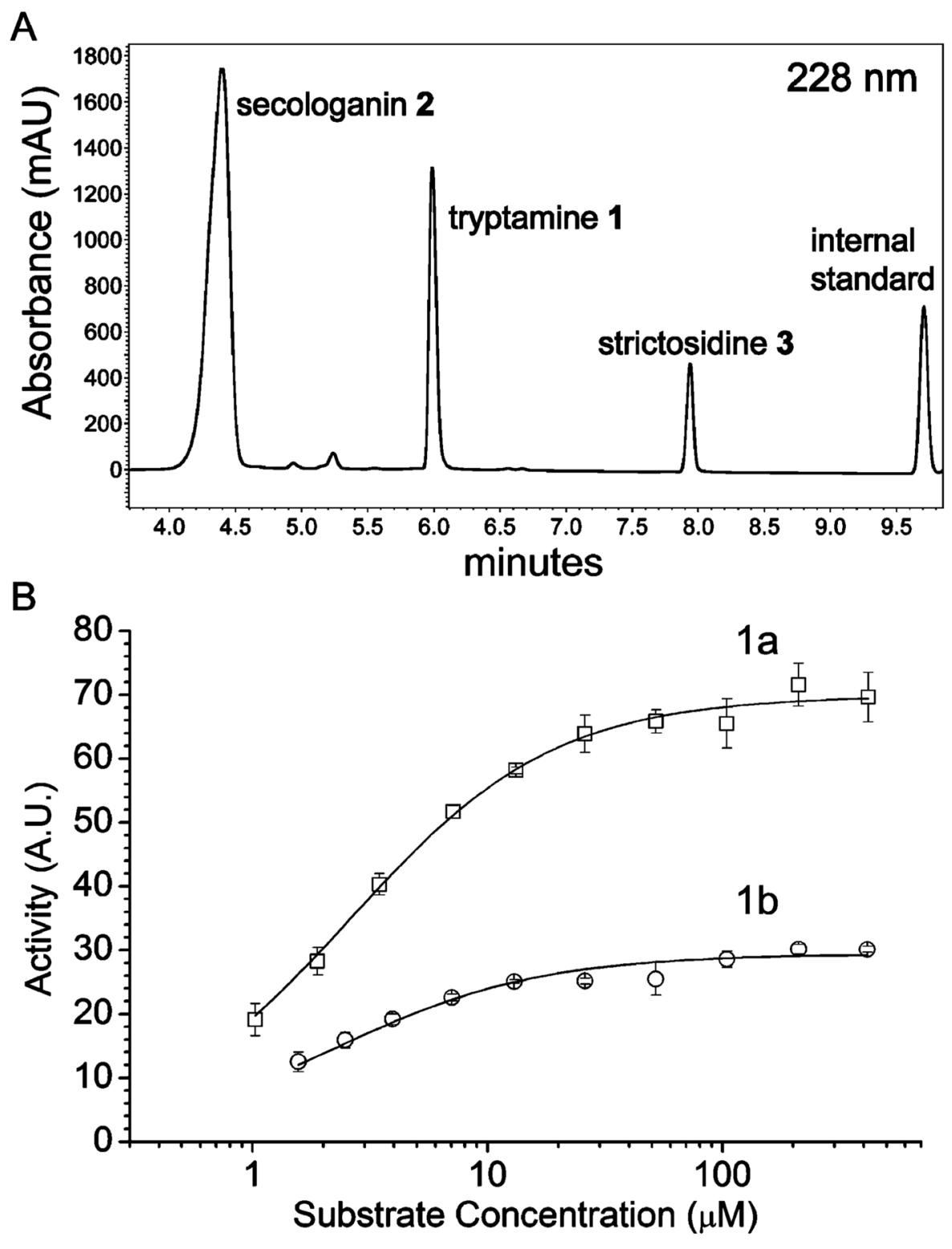

Figure 3.

(A) Representative HPLC trace for enzyme catalyzed reaction of tryptamine 1a with secologanin 2 to yield strictosidine 3 . Under quench conditions, the methyl ester of secologanin and strictosidine have been hydrolyzed. (B) Representative kinetic data for 1a and $1 \mathbf{b}\left(2.5 \mathrm{mM}\right.$ secologanin 2, $80 \mathrm{nM}$ strictosidine synthase, $\left.30^{\circ} \mathrm{C}\right)$ obtained using this assay. 


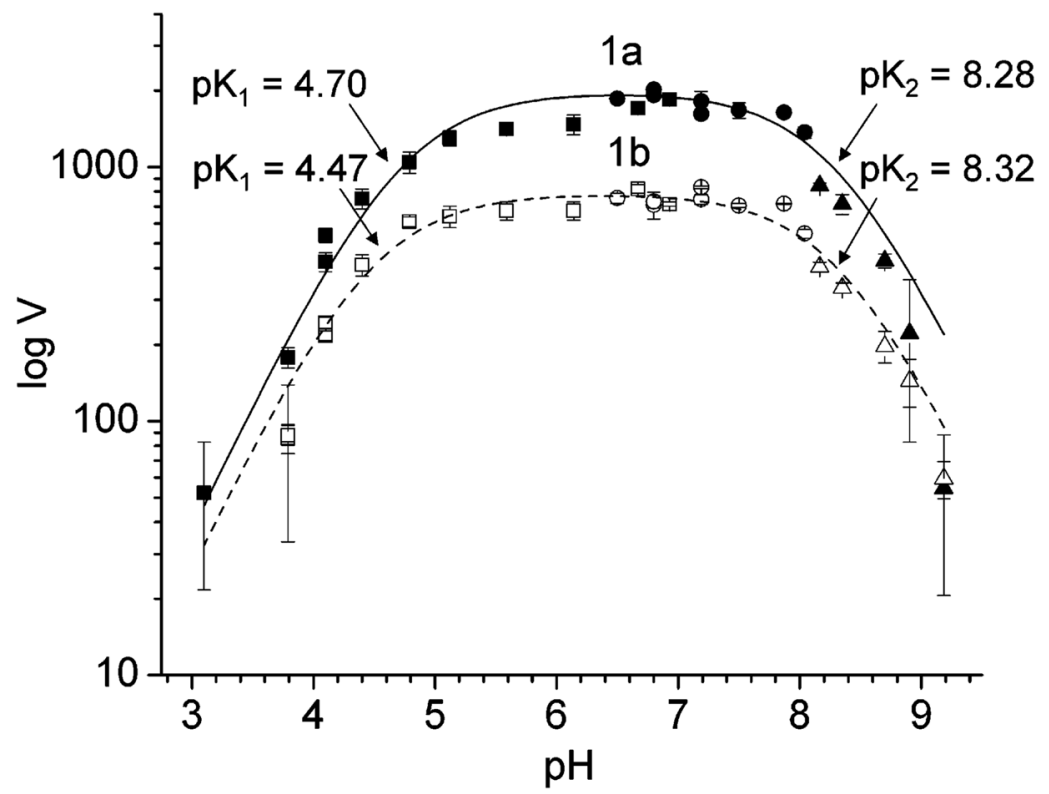

Figure 4.

$\mathrm{pH}$ profile of enzymatic activity under saturating $\left(V_{\max }\right)$ substrate conditions. Tryptamine 1a is represented by filled symbols; $\left[2-{ }^{2} \mathrm{H}\right]$-tryptamine $\mathbf{1 b}$ is represented by open symbols. Circles, squares, triangles represent citrate, phosphate, and borate buffer conditions, respectively (see Materials and Methods). For a plot of the ${ }^{\mathrm{D}} V$ depenedence on $\mathrm{pH}$ see Supporting Information. 
A

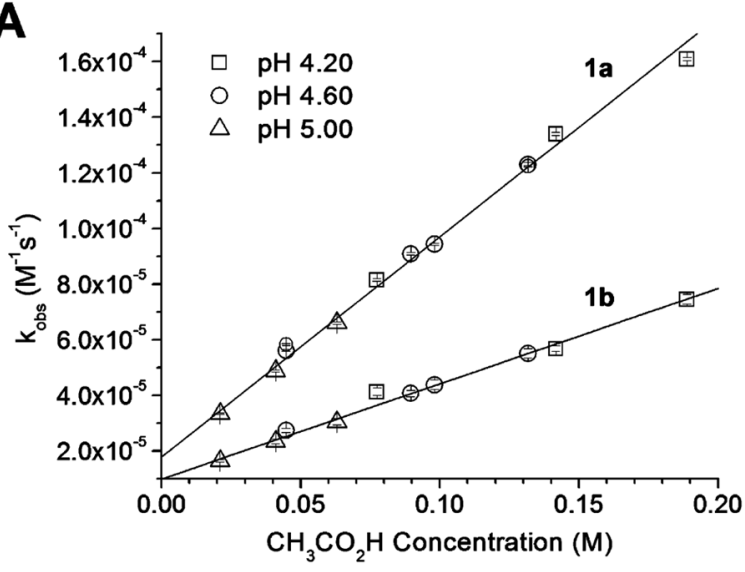

B

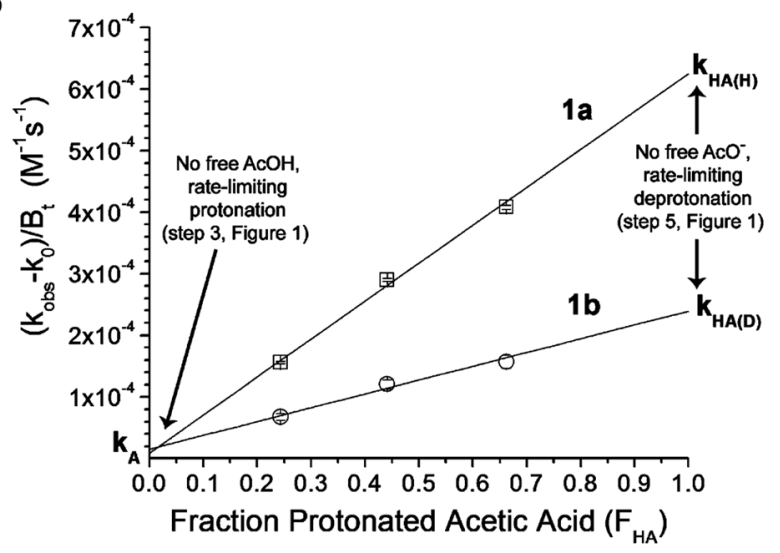

Figure 5.

(A) Apparent second-order rate constants plotted against concentration of acetic acid $\mathrm{CH}_{3} \mathrm{CO}_{2} \mathrm{H}[\mathrm{AcOH}]$ for tryptamine $1 \mathbf{a}$ and $\mathbf{1 b}$. (B) Plotted rate constants are normalized for total buffer concentration $\left(B_{\mathrm{t}}\right)$. By extrapolation, the KIE is 1 for $k_{\mathrm{A}}$ (the limiting rate constant for $\mathrm{AcO}^{-}$in the absence of acid) and 2.65 for $k_{\mathrm{HA}}$ (the limiting rate constant for $\mathrm{AcOH}$ in the absence of general base). 


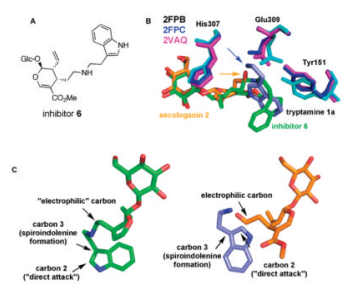

Figure 6.

(A) Structure of inhibitor 6. (B) Overlay of 6 (in green) with tryptamine 1a (in blue, from 2FPB) and secologanin 2 (in orange, from 2FPC). The aldehyde of secologanin is highlighted with an orange arrow, and the amine of tryptamine is highlighted with a blue arrow. The indole moiety of 6 (from 2VAQ) does not overlay well with 1a. Surrounding amino acids from 2FPB, 2FPC, and inhibitor structure (3.0 ̊ resolution) are shown for comparison (tryptamine complex, 2FPB, cyan; secologanin complex, 2FPC, blue; inhibitor complex, 2VAQ, magenta). (C) Detail of the structure of inhibitor 6 as it crystallized in the strictosidine synthase active site. The nucleophilic carbons 2 and 3 (highlighted by arrows) are distant from the electrophilic carbon of the iminium species (highlighted by arrow). The methyl ester of inhibitor $\mathbf{6}$ is omitted for clarity. The structures of tryptamine $\mathbf{1 a}$ (in blue, from 2FPB) and secologanin 2 (in orange, from 2FPC) are shown for comparison. 


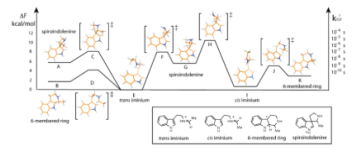

Figure 7.

Free energy $\Delta F$ minima (represented by structures A, B, E, G, I, K) and transition states (represented by structures C, D, F, H, J in brackets) plotted to show the connectivity of the free energy landscape. The timescales on the right are from transition-state theory and reflect the time scale for passage through each column from the trans-iminium state. There is also a pathway from spiroindolenine $\mathrm{A}$ to six-membered ring $\mathrm{K}$ through a higher-energy transition state $12.43 \mathrm{kcal} / \mathrm{mol}$ above the trans-iminium species. 


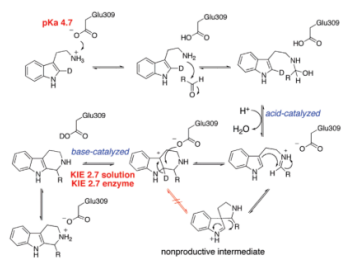

Figure 8.

Proposed mechanism of strictosidine synthase involving Glu309 and protonated tryptamine $1 a$. 


$$
\text { Intermediate } \stackrel{\substack{\mathrm{k}_{\mathrm{I}} \text { [Aldehyde] } \\
\mathrm{k}_{-\mathrm{I}}} \begin{array}{c}
\text { Tryptamine } \\
+
\end{array}}{\text { Aldehyde }} \underset{\mathrm{k}_{-\mathrm{P}}}{\stackrel{\mathrm{k}_{\mathrm{P}}}{\rightleftharpoons}} \text { Product }
$$

Scheme 1. 
Table 1

Data Collection and Refinement Statistics of Strictosidine Synthase-Inhibitor Complex

\begin{tabular}{|c|c|}
\hline wavelength $(\AA)$ & 0.8148 \\
\hline space group & $R 3$ \\
\hline \multirow[t]{3}{*}{ Unit Cell $(\AA)$} & \\
\hline & $a=b=150.0$ \\
\hline & $c=121.7$ \\
\hline total reflections & 119018 \\
\hline unique reflections & 20319 \\
\hline mosaicity & 1.0 \\
\hline resolution $(\AA)$ & $20-3.00$ \\
\hline completeness (\%) & $100(100)^{a}$ \\
\hline$I / \sigma(I)$ & $18.1(3.6)$ \\
\hline$R_{\text {merge }}(\%)^{b}$ & $10.1(52.9)$ \\
\hline resolution $(\AA)$ & $20-3.00$ \\
\hline$R_{\text {cryst }} / R_{\text {free }}(\%)^{c}$ & $18.7 / 24.7$ \\
\hline average $B(\AA)$ for protein & 48.6 \\
\hline average $B(\AA)$ for inhibitor & 52.4 \\
\hline average B $(\AA)$ for water & 30.5 \\
\hline \multicolumn{2}{|l|}{ Number of Atoms } \\
\hline non-hydrogen & 4896 \\
\hline water & 14 \\
\hline \multicolumn{2}{|l|}{ rms Deviations } \\
\hline bond ( $\AA$ ) & 0.019 \\
\hline angles (deg) & 1.94 \\
\hline
\end{tabular}

\footnotetext{
${ }^{a}$ The values in parentheses correspond to the last resolution shell.

${ }^{b} R_{\text {merge }}=\Sigma_{h k l} \Sigma_{i}\left|I_{i}(h k l)-\langle I(h k l)\rangle\right| / \Sigma_{h k l} \Sigma_{i}\left\langle I_{i}(h k l)\right\rangle$, where $\langle I(h k l)\rangle$ is the average intensity over symmetry-equivalent reflections.

${ }^{c} R_{\text {cryst }}\left(R_{\text {free }}\right)=\Sigma h k l\left\|F_{\mathrm{O}}(h k l)|-| F_{\mathrm{C}}(h k l)\right\| / \Sigma_{h k l}\left|F_{\mathrm{O}}(h k l)\right|$, where $F_{\mathrm{O}}$ and $F_{\mathrm{c}}$ are observed and calculated structure factors, respectively.
} 